\title{
Upper Cretaceous Subsurface Stratigraphy and Structure of Coastal Georgia and South Carolina
}

GEOLOGICALSURVEY PROFESSIONAL PAPER 1222

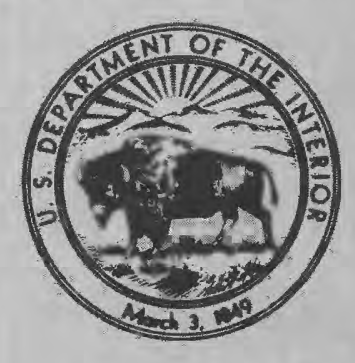




\section{Upper Cretaceous Subsurface Stratigraphy and Structure of Coastal Georgia and South Carolina}

By PAGE C. VALENTINE

GE OLOGICAL SUR VEY PROFESSIONAL PAPER 1222

$A$ study based on 24 wells along transects

from the Southeast Georgia Embayment

northeastward to the Cape Fear Arch and

offshore to the Outer Continental Shelf

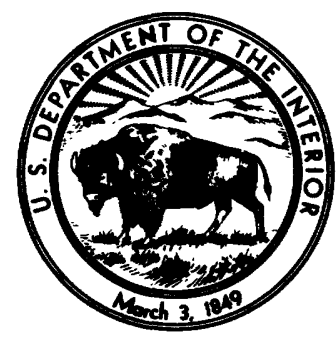




\section{UNITED STATES DEPARTMENT OF THE INTERIOR}

JAMES G. WATT, Secretary

GEOLOGICAL SURVEY

Dallas L. Peck, Director

\section{Library of Congress Cataloging in Publication Data}

Valentine, Page C.

Upper Cretaceous subsurface stratigraphy and structure of coastal Georgia and South Carolina.

(Geological Survey professional paper ; 1222)

"A study based on 24 wells along transects from the Southeast Georgia Embayment northeastward to the Cape Fear Arch and offshore to the Outer Continental Shelf."

Bibliography: $p$.

Supt. of Docs. no.: I 19.16:1222

1. Geology, Stratigraphic-Cretaceous. 2. Geology-Georgia. 3. Geology-South Carolina. 4. Coasts-Georgia. 5. Coasts-South Carolina. I. Title. II. Series: United States. Geological Survey. Professional paper ; 1222.

QE688.V35 551.7'7'09757 80-607868

For sale by the Distribution Branch, U.S. Geological Survey, 604 South Pickett Street, Alexandria, VA 22304 


\section{CONTENTS}

Abstract

Introduction

Acknowledgments

Regional geology

Upper Cretaceous stratigraphy

Cenomanian-Turonian European Stage boundary

COST GE-1 well, Outer Continental Shelf off Georgia

Age of pollen zone IV

Fripp Island well, South Carolina

Parris Island No. 2 well, South Carolina

\begin{tabular}{r|r} 
Page & Upper Cretaceous stratigraphy-Continued \\
1 & Clubhouse Crossroads corehole 1, South Carolina \\
2 & Penny Royal and Myrtle Beach wells, South Carolina; \\
2 & Calabash well, North Carolina \\
2 & Georgia Geological Survey wells, southeastern Georgia \\
5 & Wells in the axis of the Southeast Georgia Embayment \\
10 & Ages of subsurface stratigraphic units - \\
11 & Geologic section of northern Florida and coastal Georgia and \\
13 & Summary Carolina \\
15 & References cited
\end{tabular}

Page

\section{ILLUSTRATIONS}

FIGURE 1. The southeastern Atlantic continental margin showing location of wells, geologic sections, and structural features

2. Diagram showing Cretaceous stratigraphic units recognized in previous studies of coastal Georgia and South Carolina and the authors' correlation of their units with Gulf Coast and European stages

3. Diagram showing correlation of upper Cenomanian and lower Turonian stratigraphic units of parts of Europe and the United States

4-9. Diagrams showing stratigraphic correlations of wells based on results of this study and comparisons with previous stratigraphic interpretations:

4. Fripp Island well, South Carolina

5. Parris Island No. 2 and Fripp Island wells, South Carolina

6. Clubhouse Crossroads corehole 1, South Carolina

7. Penny Royal and Myrtle Beach wells, South Carolina, and Calabash well, North Carolin

8. Georgia Geological Survey wells $876,1198,724,719$, and 1197 in the Southeast Georgia Embayment, Georgia --_ east Georgia Embayment, Georgia

10. Diagram showing reinterpreted correlation of Cretaceous stratigraphic units recognized in previous studies of coastal Georgia and South Carolina with Gulf Coast and European stages

11. Diagram showing stratigraphic correlation along section $(A-A)$ through the Southeast Georgia Embayment and the Cape Fear Arch, Florida, Georgia, and South Carolina

\section{TABLE}

TABLE 1. Well number, name, location, altitude, and depth of 24 wells drilled in coastal South Carolina and Georgia, northern Florida, and offshore 



\title{
UPPER CRETACEOUS SUBSURFACE STRATIGRAPHY AND STRUCTURE OF COASTAL GEORGIA AND SOUTH GAROLINA
}

\author{
By Page C. Valentine
}

\begin{abstract}
Upper Cretaceous subsurface stratigraphy and structure of coastal Georgia and South Carolina is based on the study of 24 wells along two transects, one extending across the seaward-dipping sedimentary basin termed the "Southeast Georgia Embayment" northeastward to the crest of the Cape Fear Arch, and the other alined east-west, parallel to the basin axis and including the COST GE-1 well on the Outer Continental Shelf. A new biostratigraphic analysis, using calcareous nannofossils, of the Fripp Island, S.C., well and reinterpretations of the Clubhouse Crossroads corehole 1, South Carolina, and other wells in South Carolina, Georgia, and northernmost Florida have made possible the comparison and reevaluation of stratigraphic interpretations of the region made by G. S. Gohn and others in 1978 and 1980 and by P. M. Brown and others in 1979. The present study indicates that within the Upper Cretaceous section the stratigraphic units formerly assigned a Cenomanian (Eaglefordian and Woodbinian) age are Coniacian (Austinian) and Turonian (Eaglefordian) in age. A previously described hiatus encompassing Coniacian and Turonian time is not present. More likely, a hiatus is probably present in the upper Turonian, and major gaps in the record are present within the Cenomanian and between the Upper Cretaceous and the preCretaceous basement.

After an erosional episode in Cenomanian time that affected the section beneath eastern Georgia and South Carolina, Upper Cretaceous marine clastic and carbonate rocks were deposited on a regionally subsiding margin that extended to the present Blake Escarpment. In contrast, during Cenozoic time, especially in the Eocene, subsidence and sedimentation rates were uneven across the margin. A thick progradational sequence of carbonate rocks accumulated in the Southeast Georgia Embayment and also built the present Continental Shelf, whereas farther offshore a much thinner layer of sediments was deposited on the Blake Plateau.

There is no general agreement on the exact placement of the Cenomanian-Turonian boundary in Europe or the United States Western Interior, and the widespread Sciponoceras gracile ammonite zone represents an interval of equivocal age between accepted Cenomanian and Turonian strata. The extinction of the foraminifer genus Rotalipora took place within the Sciponoceras gracile zone; it is used here to identify the Cenomanian-Turonian boundary.

Pollen zone IV (Complexiopollis-A tlantopollis assemblage zone) is an important and widespread biostratigraphic unit characterized by a distinctive spore and pollen flora. It is consistently associated with lower Turonian calcareous nannofossils on the Atlantic continental margin; these nannofossil assemblages are also present in pollen zone IV, in strata that encompass the Sciponoceras gracile zone and the lower part of the Mytiloides labiatus zone in the Gulf Coastal Plain at Dallas, Tex.
\end{abstract}

\section{INTRODUCTION}

Numerous wells have been drilled along the coasts of South Carolina and Georgia, and many of these have reached pre-Cretaceous basement. Previous investigators of these wells have outlined the subsurface geology of the region. Their studies were based primarily on lithologic and electric log correlations supplemented by paleontological interpretations. However, the results of the most recent and extensive investigations of the Upper Cretaceous stratigraphy in the subsurface of the coastal region do not agree on the placement of hiatuses in the rock record or on the age of the lower part of the sedimentary section that lies above pre-Cretaceous basement (Brown and others, 1979; Gohn and others, 1978a, 1980, and in press).

The drilling of the COST GE-1 well on the Continental Shelf off southeastern Georgia provided an opportunity to investigate the paleontology of a thick section $(2,300$ ft) of Upper Cretaceous strata (Scholle, 1979). Biostratigraphic studies of the sedimentary strata penetrated by this well revealed a nearly complete section of Upper Cretaceous limestone that includes strata of Coniacian Age and Turonian Age, and a thin, unfossiliferous, apparently shallow-marine interval above the Albian that may represent the Cenomanian (Valentine, 1979a; Poag and Hall, 1979). In order to compare the Upper Cretaceous sequence at COST GE-1 with the onshore section, I made a biostratigraphic analysis of the Cretaceous calcareous nannofossils from a well drilled on Fripp Island, S.C. This well is also ideal for comparing recently published stratigraphic interpretations of the subsurface, for it was studied by Gohn and others (1978a) and is only 11 miles from a well on Parris Island, S.C., studied by Brown and others (1979) and by Gohn and others (1978a). The present study incorporates new biostratigraphic analyses into a reevalution of the Upper Cretaceous stratigraphy of coastal Georgia and South Carolina. 


\section{ACKNOWLEDGMENTS}

Two of my colleagues, R. A. Christopher and C. C. Smith of the U.S. Geological Survey (USGS), have generously allowed me to use their unpublished reports on the occurrences of spores and pollen, planktic foraminifers, and calcareous nannofossils from the subsurface of South Carolina and Georgia; these reports form the paleontological basis for the stratigraphic interpretations of Gohn and others (1978a, 1980, and in press). I am grateful to W. A. Abbott, South Carolina Geological Survey, for providing me with the samples for the Fripp Island well, and to R. K. Olsson, Rutgers University, for samples from the Toms River well. I wish to thank J. E. Hazel, R. A. Christopher, and Peter Popenoe of the USGS for critically reading the manuscript.

\section{REGIONAL GEOLOGY}

The region of coastal South Carolina and Georgia and northern Florida that is treated in this study includes the southwest flank of the Cape Fear Arch and the Southeast Georgia Embayment (fig. 1). The embayment is a seaward-dipping sedimentary basin bounded on the northeast by the Cape Fear Arch, on the southwest by the Peninsular Arch, and on the west by the Piedmont province. Marine carbonate and clastic strata, chiefly of Late Cretaceous and Cenozoic age, are 4,600 ft thick beneath the southeastern Georgia Coastal Plain. Offshore, the basin descends dramatically to at least 11,000 $\mathrm{ft}$ below sea level at COST GE-1, near the shelf edge, where the section also includes 5,000 feet of Lower Cretaceous rocks. I outlined the stratigraphy and structure of the Southeast Georgia Embayment in a previous paper (Valentine, 1979b). Seaward of the FloridaHatteras slope, the Southeast Georgia Embayment opens into the much deeper $(40,000 \mathrm{ft})$ Blake Plateau basin (Dillon and others, 1979).

In the deepest part of the Southeast Georgia Embayment onshore, the basal sedimentary strata in some wells may constitute a thin (possibly $150 \mathrm{ft}$ ) sequence of undated nonmarine to marginal-marine clastic rocks. These rocks are overlain by a transgressive sequence of Upper Cretaceous marine clastic strata $(\sim 650 \mathrm{ft}$ ), which are surmounted by marine carbonate beds $(\sim 1,150 \mathrm{ft})$ of latest Cretaceous age. The marine clastic facies thickens northeastward along the coastline to include the entire Upper Cretaceous and extends over Cape Fear Arch, where it is $1,300 \mathrm{ft}$ thick. The Upper Cretaceous marine carbonate facies is confined to the center of the basin, but it is overlain by a widespread, thick $(2,100 \mathrm{ft})$ carbonate wedge of Paleocene, Eocene, and Oligocene age that thins to the northeast and is absent over the Cape Fear Arch.

\section{UPPER CRETACEOUS STRATIGRAPHY}

The results of drilling into the Cretaceous deposits along the coasts of Georgia and South Carolina and in northern Florida have been reported by many authors, including Applin (1955), Herrick (1961), Herrick and Vorhis (1963), Applin and Applin $(1965,1967)$, Marsalis (1970, paleontology by S. M. Herrick and E. R. Applin), Maher (1971, paleontology by E. R. Applin), Cramer (1974), Zupan and Abbott (1976), Brown and others (1979), and Gohn and others (1978a, 1980, and in press). Several of these studies deal with the subsurface stratigraphy on a regional basis.

Maher (1971) used a combination of lithostratigraphic units and Gulf Coast stages in his broad-scale study of the Atlantic coastal province. However, he did not indicate the presence of major unconformities in the Upper Cretaceous coastal section of Georgia and South Carolina, nor did he correlate his stratigraphic units with European stages. Brown and others (1979) extended into the South Carolina and Georgia subsurface the Cretaceous stratigraphic framework established by Brown and others (1972) for the Coastal Plain north of Cape Fear, and the stratigraphic units are considered by the authors to be chronostratigraphic in nature. Although Brown and others (1979) did not document their interpretations in Georgia and South Carolina, they presumably used the same guidelines as those used in the earlier study (Brown and others, 1972), and the delineation of stratigraphic units apparently is heavily dependent on lithology and the presence of a limited number of ostracode and foraminifer guide fossils. The type sections of these units (Brown and others, 1972) are in the subsurface of North Carolina, just north of the region under study here. Brown and others $(1972,1979)$ equated their stratigraphic units primarily with Gulf Coast provincial stages. In the other recent studies of the region, Gohn and others $(1978 \mathrm{a}, 1980)$ recognized a sequence of Cretaceous lithostratigraphic units in the subsurface of coastal Georgia and South Carolina and correlated them with both European and Gulf Coast stages on the basis of analyses of spores and pollen, planktic foraminfers, and calcareous nannofossils. In the following discussion of the stratigraphic units of Gohn and others (1978a, 1980) and Brown and others (1979), the Gulf Coast and European stage equivalents of each unit are those given by Gohn and others and Brown and others, unless otherwise stated.

The stratigraphic interpretations of Brown and others (1979) and Gohn and others (1978a, 1980) differ in several aspects; a comparison of their results and a correlation by those authors of their units with Gulf Coast and European stages is shown in figure 2. Brown and others (1979) indicated the presence of a regional hiatus 


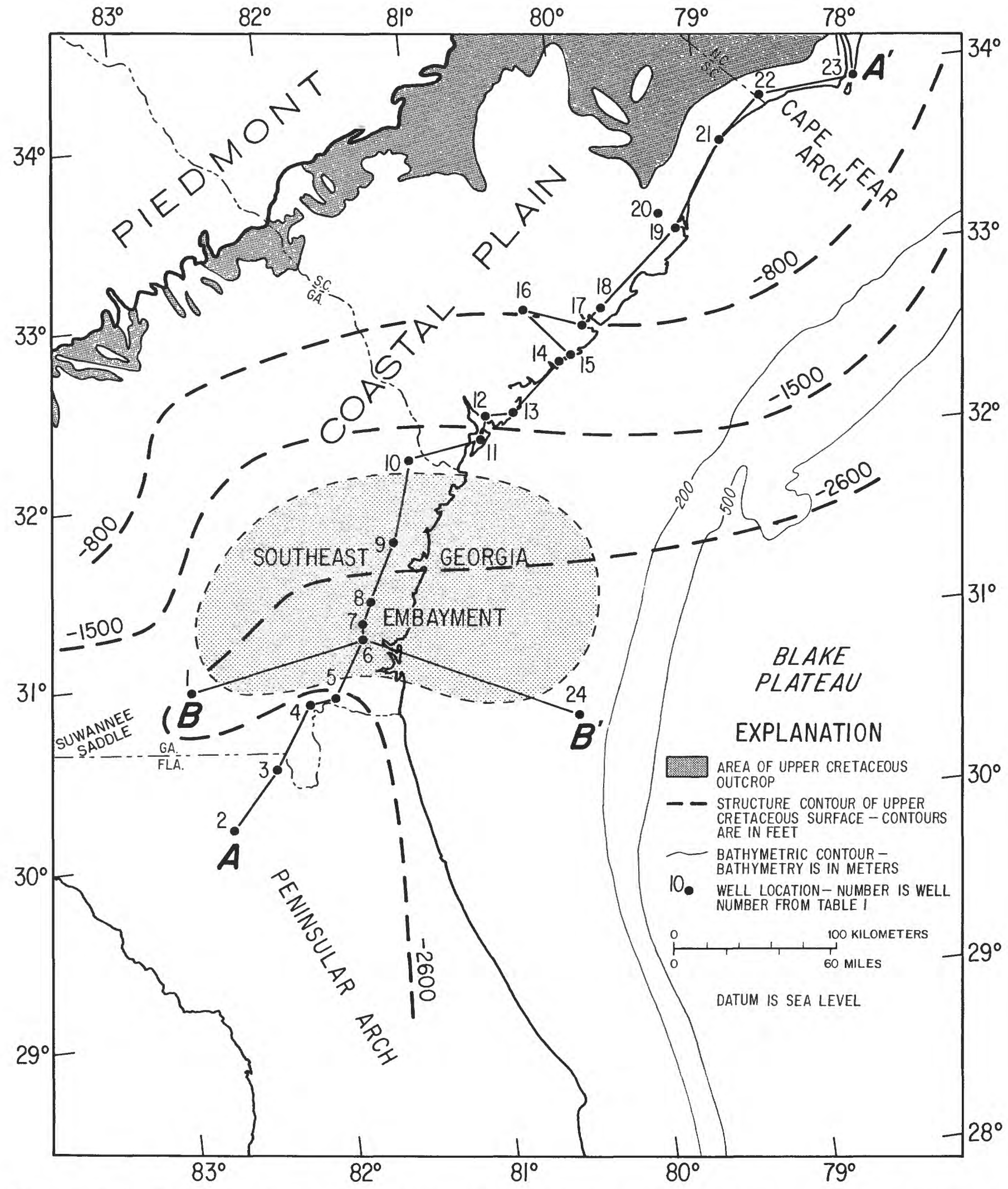

FIGURE 1. - The southeastern Atlantic continental margin, showing locations of wells, geologic sections, and structural features. See table 1 for names and altitudes of wells. Data used in drawing Upper Cretaceous structure contours include additional wells not shown here (Herrick and Vorhis, 1963; Applin and Applin, 1967; Maher, 1971; Cramer, 1974; Hathaway and others, 1979). 


\begin{tabular}{|c|c|c|c|}
\hline $\begin{array}{c}\text { Brown } \\
\text { and others } \\
(1979) \\
\end{array}$ & $\begin{array}{c}\text { Provincial } \\
\text { Stage }\end{array}$ & $\begin{array}{c}\text { European } \\
\text { Stage }\end{array}$ & $\begin{array}{c}\text { Gohn } \\
\text { and others } \\
\text { (1978a,1980) }\end{array}$ \\
\hline$A$ & Navarroan & Maestrichtian & \\
\hline B & Tayloran & Campanian & \\
\hline \multirow{2}{*}{ C } & \multirow{2}{*}{ Austinian } & Santonian & K< \\
\hline & & Coniacian & \\
\hline \multirow{2}{*}{ D } & \multirow{2}{*}{$\begin{array}{l}\text { Eagle- } \\
\text { fordian }\end{array}$} & Turonian & \\
\hline & & \multirow{3}{*}{ Cenomanian } & \\
\hline$E$ & Woodbinian & & \\
\hline & \multirow{2}{*}{$\begin{array}{l}\text { Washitan } \\
\text { and } \\
\text { Fredericks- } \\
\text { burgian }\end{array}$} & & \\
\hline & & Albian & \\
\hline
\end{tabular}

FigURE 2. - Cretaceous stratigraphic units of coastal Georgia and South Carolina recognized by Brown and others (1979), Gohn and others (1978a, 1980), and those authors' correlation of their units with Gulf Coast (Provincial) and European stages. Cross-hatched zones represent hiatuses. Note differences in the placement of hiatuses and in the ages of the oldest rocks above pre-Cretaceous basement. 
within the Cenomanian between units D (Eaglefordian) and $E$ (Woodbinian). In contrast, Gohn and others (1978a, 1980) recognized a major hiatus between the Santonian (unit K4, middle to upper Austinian) and the Upper Cenomanian (unit K3, middle Eaglefordian) and indicated that the Turonian and Coniacian are absent in this region. With regard to the lowermost sedimentary beds in the section, Brown and others (1979) recognized, in units $\mathrm{E}$ and $\mathrm{F}$, strata as old as middle Cenomanian to Albian (Woodbinian, Washitan, and Fredericksburgian). On the other hand, the oldest beds recognized by Gohn and others $(1978 \mathrm{a}, 1980)$ are their units K3 and K2 (upper Cenomanian, middle Eaglefordian) and unit K1, which was designated upper Cenomanian in South Carolina and later revised to be Upper(?) Cretaceous in their study of the Georgia subsurface.

In the present study of the regional Cretaceous stratigraphy, I have attempted to show the relations between stratigraphic units recognized by other authors and to date these units on the basis of their fossil assemblages. The results of one aspect of this study indicate that previous authors have underestimated the thickness of the Santonian-Coniacian (lower and middle Austinian) stages and have overestimated the ages of several of their lower stratigraphic units. I believe that Coniacian and, in particular, Turonian strata are present beneath the coasts of Georgia and South Carolina and that the Cenomanian, if present, is a relatively thin unit above the pre-Cretaceous basement. These conclusions rest on the recognition of Turonian fossil assemblages and ultimately on the placement of the Cenomanian-Turonian Stage boundary in Europe and North America.

Unless otherwise indicated, in the stratigraphic descriptions that follow, the depths of samples and stratigraphic boundaries in onshore wells are given in feet as originally designated during drilling, whereas COST GE-1 depths are given relative to sea level. Table 1 gives locations and altitudes of the wells.

\section{CENOMANIAN-TURONIAN EUROPEAN STAGE BOUNDARY}

The boundary between the Cenomanian and Turonian Stages is ill defined both faunally and lithologically. D'Orbigny $(1842,1847)$ erected these stages on the basis of their molluscan assemblages, but he did not designate type sections. However, he stipulated the city of LeMans as the type area for the Cenomanian and, somewhat to the south, the environs of Tours as the type area for the Turonian. In the years since d'Orbigny's original descriptions, many geologists have studied these areas, and they have established a biostratigraphic zonation based primarily on ammonites and inoceramids. The stratigraphic interpretations of many of the recent European and North American studies are shown in figure 3.

At present, there is no universal agreement either on the physical placement of the Cenomanian-Turonian boundary or on a biostratigraphic definition of it. It has been drawn at various levels within a stratigraphically short interval above the upper Cenomanian strata of the Calycoceras naviculare zone (as used by Kennedy and Juignet, $1973 ;=$ Eucalycoceras pentagonumCalycoceras naviculare zone of Kennedy and Hancock, 1976) and below lower Turonian strata of the Mammites nodosoides-Inoceramus labiatus zone. These two molluscan zones are widespread and have been recognized in both Europe and North America. The intervening stratigraphic units are characterized in the type areas of France by beds of variable lithology that show lateral facies changes, and they are frequently bounded by unconformities and contain relatively poor fossil assemblages.

During the time between the deposition of strata of the upper Cenomanian Calycoceras naviculare zone and that of the lower Turonian Mammites nodosoidesInoceramus labiatus zone, a major evolutionary event took place in many groups of organisms, including the ammonites, inoceramids, and foraminifers (Kauffman and others, 1976). Early studies of the European type areas reported a lack of ammonite faunas in this interval, but subsequent collecting has revealed the presence of a distinctive assemblage representative of the Sciponoceras gracile zone that was recognized first in the Western Interior of the United States (Cobban and Reeside, 1952; Cobban and Scott, 1972) and is now known also in northern France and southern England (Kennedy and Hancock, 1976). A composite faunal assemblage of North American and European elements characteristic of this zone would include, among others, the belemnite Actinocamax plenus, the ammonites Kanabiceras septemseriatum, Metoicoceras geslinianum, M. gourdoni, $M$. whitei, Sciponoceras gracile, Worthoceras vermiculum, and the bivalve Inoceramus pictus.

Strata assigned to the Sciponoceras gracile zone in the Cenomanian type area are the Sables à Catopygus obtusus and the overlying Craie à Terebratella carantonensis (= Horizon A; Kennedy and Juignet, 1973; Kennedy and Hancock, 1976). In the Turonian type area, elements of the Sciponoceras gracile assemblage have been reported from the Craie marneuse at the base of the Turonian in the Fretevou section (Rawson and others, 1978). In northern France and southeastern England, the lower part of the Sciponoceras gracile zone includes the Actinocamax plenus marls (Metoicoceras geslinianum and $M$. gourdoni zones of Jefferies, 1962), and, in Devon, southwestern England, the upper part of 
UPPER CRETACEOUS SUBSURFACE STRATIGRAPHY, STRUCTURE, GEORGIA, SOUTH CAROLINA

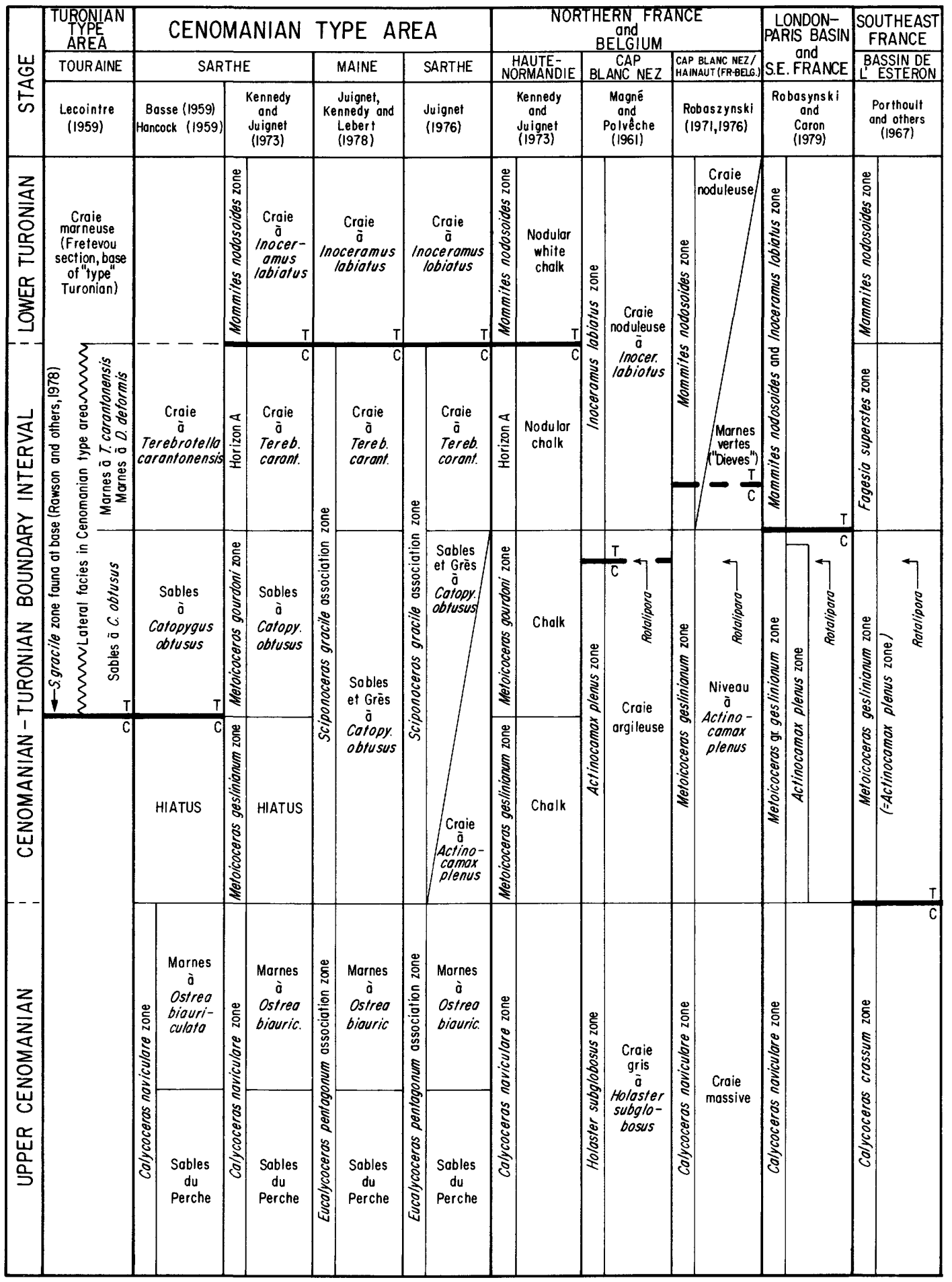

FIGURE 3.- Correlation of upper Cenomanian and lower Turonian stratigraphic units of France (including the type areas), Belgium, England, and the United States Western Interior and Gulf Coastal Plain. Zonation based on ammonites and bivalves. Ranges of Rotalipora and elements of the Sciponoceras gracile assemblage zone are shown in the Cenomanian-Turonian boundary interval. No vertical scale. Formation names at Pueblo, Colo. also apply to the section in western Kansas. At Dallas, Tex., J. D. Powell of Grand Junction, Colo., studied outcrops; R. A. Christopher (USGS) and Valentine studied the same core. Heavy horizontal line indicates Cenomanian-Turonian boundary of various authors; dashed where approximate. 


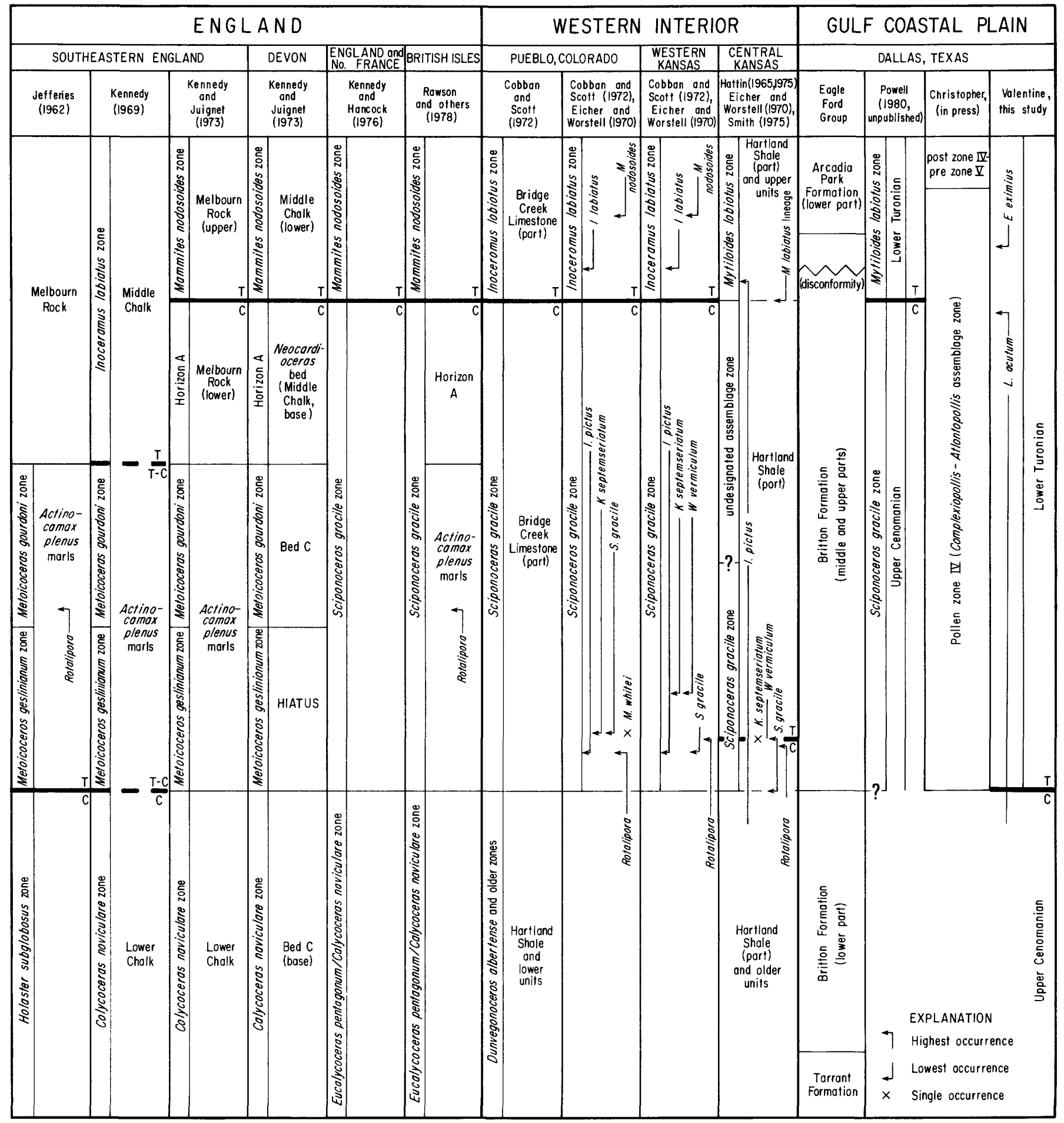

FIgure 3. - Continued. 
TABLE 1.-Well number, name, location, altitude, and depth of 24 wells drilled in coastal South Carolina and Georgia, northern Florida, and offshore

[Sources of data: (1) Applin and Applin, 1967; (2) Brown and others, 1972; (3) Brown and others, 1979; (4) Gohn and others, 1978a; (5) Scholle, 1979. GGS = Georgia Geological Survey well number] $\quad$ Total depth Source

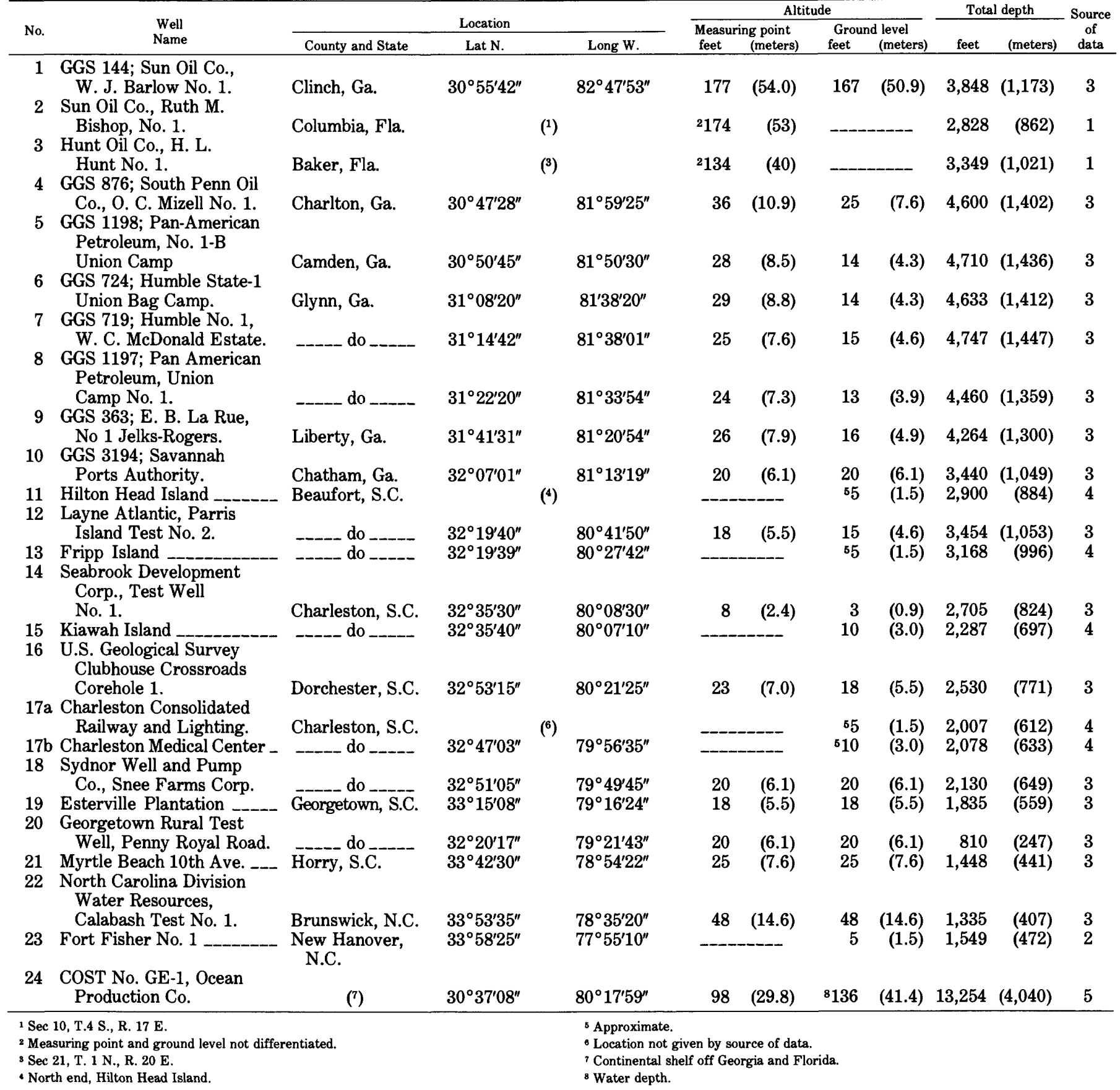


the Lower Chalk; the upper part of the Sciponoceras gracile zone is equivalent to Horizon A in HauteNormandie, the lower part of the Melbourne Rock in southeastern England, and the Neocardioceras pebble bed at the base of the Middle Chalk in Devon (Kennedy and Juignet, 1973; Kennedy and Hancock, 1976). In southeastern France, strata corresponding in age to the Actinocamax plenus marls have also been recognized (Porthault and others, 1967). In the Western Interior United States, the Sciponoceras gracile zone is in the lower part of the Bridge Creek Limestone Member of the Greenhorn Limestone in Pueblo County, Colo., and Hamilton County, western Kansas (Cobban and Scott, 1972), and in the lower part of the Hartland Shale Member of the same formation in Russell County, central Kansas (Hattin, 1975). The $S$. gracile assemblage is, therefore, distinctive and widespread geographically; it is commonly confined to a few feet of section between recognized Cenomanian and Turonian rocks, and it represents an interval of time during which ammonites and other fossil groups underwent a remarkable evolutionary change.

A review of selected recent papers on the Cenomanian-Turonian boundary reveals that as study of the problem has progressed, the boundary has been raised from the basal part of the present Sciponoceras gracile zone to the top of that zone. These studies (fig. 3) have been based chiefly on the stratigraphic ranges of ammonites and inoceramids. Lecointre (1959) attempted to clarify the stratigraphy in France by proposing a Turonian type section in the Cher Valley near the type area originally described by d'Orbigny $(1842,1847)$. Lecointre placed the Cenomanian-Turonian boundary at the base of the Craie inarneuse in the Fretevou section and suggested that those beds were laterally equivalent to other facies in the Cenomanian type area, namely the Marnes à Terebratella carantonensis, the Marnes à Ditrupa deformis, and the Sables à Catopygus obtusus.

As a result of more recent studies in northern France and southern England, however, the CenomanianTuronian boundary has been moved higher in the section (Kennedy and Juignet, 1973; Juignet, 1976; Kennedy and Hancock, 1976; Juignet and others, 1978). In the Cenomanian type area, those authors have drawn the boundary between the Craie à Terebratella carantonensis (top of both Horizon A and the Sciponoceras gracile zone) and the Craie à Inoceramus labiatus (Mammites nodosoides zone); in northern France and southeastern England, the boundary was placed at the top of Horizon A, which overlies the Actinocamax plenus marls.

In the Western Interior United States, Cobban and Scott (1972) tentatively recognized the CenomanianTuronian boundary at the same position, between the Sciponoceras gracile zone below and the Inoceramus labiatus zone above, and subsequent studies have drawn the boundary at that level (Kauffman and others, 1976, 1977).

Although the many studies of Cenomanian and Turonian strata have not resulted in general agreement on the placement of the boundary, they have succeeded in delineating a short, faunally distinctive stratigraphic interval, the Sciponoceras gracile zone, within which the Cenomanian-Turonian boundary undoubtedly lies. The beds assigned to this zone represent a transitional interval between strata of undisputed Cenomanian and undisputed Turonian Age, a conclusion reached by Magné and Polvêche (1961) in their study of the Actinocamax plenus zone. The concept of a transitional zone encompassing a stage boundary may not be philosophically acceptable to all stratigraphers, but it seems to best characterize the stratigraphic relations that typify the beds assigned to the Sciponoceras gracile zone. The difficulty in determining the exact placement of the Cenomanian-Turonian boundary will remain unresolved as long as no type sections are recognized for these two stages.

Molluscan faunal assemblages historically have been the basis for the highly successful biostratigraphic zonation of Cenomanian and Turonian strata in both Europe and the United States Western Interior. However, as a practical matter, stratigraphers must also be able to recognize the Cenomanian-Turonian boundary by using other biostratigraphically important groups such as planktic foraminifers and calcareous nannofossils. Studies of European and North American sections have shown that a major evolutionary event, the extinction of the planktic foraminifer genus Rotalipora, took place within the Cenomanian-Turonian transition zone described above. Planktic foraminifers are poorly preserved in this interval in the Cenomanian and Turonian type areas (Marks, 1977), but they are well represented in coeval beds elsewhere in Europe and North America. More precisely, the rotaliporids became extinct during deposition of the Actinocamax plenus beds and their equivalents in Europe and the Sciponoceras gracile zone in the United States Western Interior.

Magné and Polvêche (1961) have shown in their study of the Cenomanian-Turonian sections at Blanc-Nez and Sangatte on the north coast of France that Rotalipora became extinct in the upper part of the Actinocamax plenus zone, and they placed the Cenomanian-Turonian boundary at that level. In southern England, the last occurrence of Rotalipora is also in the upper part of the Actinocamax plenus zone (Jefferies, 1962). Similar stratigraphic relations have been reported in northern France and in the Hainaut region of Belgium and France (Robaszynski, 1971, 1976) and also in 
southeastern France (Porthault and others, 1967). The Rotalipora extinction datum has also been delineated in the United States Western Interior (Eicher and Worstell, 1970); a comparison of the range of Rotalipora and the ranges of ammonites and bivalves from the same sections in Colorado and Kansas (Cobban and Scott, 1972; Hattin, 1975; Smith, 1975) shows that Rotalipora became extinct in the Sciponoceras gracile zone. This relation also appears to exist in Oklahoma (Kauffman and others, 1977). The rotaliporid extinction event is widespread and easy to recognize, and I follow the practice of many stratigraphers (Pessagno, 1969; van Hinte, 1976) who have adopted it as a reliable datum for the practical determination of the CenomanianTuronian boundary.

\section{COST GE-1 WELL, OUTER CONTINENTAL SHELF OFF GEORGIA}

Several investigators have conducted biostratigraphic studies of calcareous nannofossils, planktic foraminifers, and palynomorphs from the COST GE-1 well on the Outer Continental Shelf off southeastern Georgia (International Biostratigraphers, Inc., 1977; Amato and Bebout, 1978; Valentine, 1979a; Poag and Hall, 1979). I have determined the ranges of stratigraphically important calcareous nannofossil species in this well by examining cuttings samples (Valentine, 1979a), and the resulting biostratigraphic interpretation agrees closely with the conclusions of the other workers (Scholle, 1979, table 1).

This well is important because it provides an opportunity to compare the offshore Cretaceous stratigraphy with the onshore section of Georoia and South Carolina; it aiso allows the age of a distinctive spore and pollen flora in wells beneath the Atlantic Coastal Plain to be established on the basis of its presence in rocks containing calcareous nannofossil and foraminifer assemblages. The Tertiary-Cretaceous boundary is $3,562 \mathrm{ft}$ below sea level (water depth is $136 \mathrm{ft}$ at COST GE-1), and the Upper Cretaceous Series is a $2,140-\mathrm{ft}$ sequence of argillaceous limestones that includes Turonian through Maestrichtian rocks. An undated 150-ft-thick interval of shallow-water limestone and calcareous sandstone between Turonian and Albian rocks may mark an unconformity of Cenomanian Age. This section contrasts sharply with the onshore stratigraphy determined by Gohn and others $(1978 \mathrm{a}, 1980)$, who recognized the presence of a major hiatus representing Turonian and Coniacian time as well as recognizing a sequence of Cenomanian strata that ranges in thickness from $300 \mathrm{ft}$ at the Cape Fear Arch to about $600 \mathrm{ft}$ beneath the Georgia Coastal Plain.

Turonian beds at COST GE-1 contain a rich assemblage of calcareous nannofossils, which includes
Ahmuellerella octoradiata, Braarudosphaera bigelowii, Chiastozygus cuneatus, C. plicatus, Corollithion achylosum, C. exiguum, C. signum, Cretarhabdus conicus, C. coronadventis, C. crenulatus, Cribosphaera ehrenbergii, Cylindralithus coronatus, Eiffellithus eximius, $E$. turriseiffeli, Gartnerago segmentatum, Lithastrinus floralis, Manivitella pemmatoidea, Microrhabdulus belgicus, $M$. decoratus, Micula staurophora, Parhabdolithus angustus, $P$. embergeri, $P$. splendens, Prediscosphaera cretacea, Tranolithus orionatus, Vagalapilla matalosa, Watznaueria barnesae, $Z$ ygodiscus acanthus, $Z$. diplogrammus, and $Z$. fibuliformis. The ranges of two of these species, Corollithion achylosum and Eiffellithus eximius, are important in dating the assemblage, and I believe that their co-occurrence indicates a Turonian age.

In a worldwide study of Jurassic and Cretaceous strata involving more than 800 samples, Thierstein (1976) reported the ranges of many calcareous nannofossil species. He concluded that Corollithion achylosum ranges from the Aptian to the uppermost Turonian (Thierstein, 1976, fig. 7 and pl. 3, figs. 39, 40). I have found this species to be restricted to rocks independently dated as Turonian and older in the COST B-2, B-3, and GE-1 wells drilled on the Atlantic margin (Valentine, 1979a, 1980). A re-evaluation of the stratigraphy of the COST B-2 well (Valentine, 1980) has shown the reference to $C$. achylosum in that well (Valentine, 1977, p. 39) to be incorrect. In the Gulf Coastal Plain of Texas, C. achylosum has not been reliably reported from strata younger than Turonian (Gartner, 1968; Bukry, 1969; Smith, 1981), and in a recent unpublished study of calcareous nannofossils in a core from the Eagle Ford and Austin Groups at Dallas, Tex. (see also Christopher, in press), I found that the highest occurrence of $C$. achylosum is in the upper part of the Arcadia Park Formation (upper Turonian) and that it does not range into the overlying Atco Formation (Coniacian).

In contrast, Verbeek (1977a) reported C. achylosum to range from the upper Aptian to the Campanian, but this range is based apparently on information from an early paper by Thierstein (1973) on Lower Cretaceous biostratigraphy and does not reflect that author's later determinations (Thierstein, 1976). Moreover, Verbeek's $(1976,1977 a)$ studies in Tunisia and Spain have shown that $C$. achylosum is restricted to Turonian and older strata, except for a single occurrence in younger beds. At El Kef in Tunisia, $C$. achylosum occurs in the Cenomanian and Turonian part of the section and in two samples (18 and 19) that Verbeek (1976) at first placed in the Coniacian; later, he indicated that the lower sample (18) is Turonian in age (Verbeek, 1977a). Sample 19 is now the lowest sample in Verbeek's (1976) Mar- 
thasterites furcatus zone (Coniacian), which is defined on the first occurrence of $M$. furcatus, even though sample 18, now Turonian, also contains that species. $M$. furcatus actually may appear first in the uppermost Turonian, as indicated by Manivit and others (1979), and I have found it associated with Corollithion achylosum and Eiffellithus eximius in the Turonian of the COST B-3 well (Valentine, 1980). Therefore, Verbeek's "Coniacian" samples that contain both $C$. achylosum and $M$. furcatus probably are Turonian in age.

Eiffelithus eximius has been reported to range from the middle Turonian to the Campanian-Maestrichtian boundary (Thierstein, 1976, fig. 7, and pl. 5, figs. 28, 29; Verbeek, 1976, 1977a). Wonders and Verbeek (1977) have shown that the first occurrence of this species in the El Kef section of Tunisia is in the Turonian, above the rotaliporid extinction level; the same relation exists in a section at Javernant, France (Verbeek, 1977b; DeVries, 1977). Manivit and others (1977), in a paper on important middle Cretaceous nannofossil marker species, indicated that $E$. eximius initially appeared in the upper Turonian. Subsequently, Manivit and others (1979) showed that this species first appeared in the middle part of the Turonian.

In COST GE-1, Eiffellithus eximius and Corollithion achylosum are present in the 400-ft interval of Turonian Age from 5,302 to $5,702 \mathrm{ft}$ below sea level. The limestones in this sequence also contain spores and pollen. Cuttings samples from 5,592 to 5,602 and 5,672 to $5,682 \mathrm{ft}$, examined by $\mathrm{R}$. A. Christopher (unpub. data, 1978), were found to contain a flora representative of pollen zone IV, a biostratigraphic unit established by Doyle (1969a) in his study of the Raritan Formation of New Jersey.

\section{AGE OF POLLEN ZONE IV}

The age of pollen zone IV has an important bearing on the stratigraphic interpretations made by the present study. The zone was described from the Woodbridge Clay Member and the underlying Farrington Sand Member of the Raritan Formation in the Raritan Bay area of New Jersey (Doyle, 1969a and b, 1977; Doyle and Robbins, 1977). Work by Sirkin (1974) on Long Island and by Christopher $(1977,1979)$ in New Jersey has shown that this zone is present in the Woodbridge Clay and in the overlying Sayreville Sand Members of the Raritan Formation. Pollen zone IV, as used in the present study, refers to the upper part of the zone that is typical of these two members; in this sense, the zone has been redefined by Christopher (1979) as the Complexiopollis-Atlantopollis assemblage zone on the basis of the co-occurrence of the nominate genera and the absence of other Normapolles genera. Christopher (1977 and in press) and earlier workers dated the zone as late Cenomanian in age, but Doyle and Robbins (1977) did not rule out the possibility of an early Turonian age for the Woodbridge part of pollen zone IV.

The age of the Woodbridge Clay Member of New Jersey can be ascertained from studies by Perry and others (1975) and by Petters (1976). Perry and others (1975, figs. 11, 12) incorporated palynologic data of Doyle $(1969 \mathrm{a}, \mathrm{b})$ and Sirkin (1974) into a synthesis of Atlantic Coastal Plain stratigraphy; they used a broader definition of pollen zone IV than that described above. In New Jersey, they showed the coincidence of part of pollen zone IV with the Woodbridge Clay Member in the Toms River Chemical Co. well, and they also delineated pollen zone IV in the USGS Island Beach No. 1 well. Using planktic foraminifers, Petters (1976, p. 93, 96, fig. 6) dated the Woodbridge Clay Member as early Turonian in both the Toms River well $(1,323$ to $1,440 \mathrm{ft}$ below sea level) and the Island Beach well $(1,950$ to $2,200 \mathrm{ft}$ below sea level).

In the Island Beach well, R. A. Christopher (oral commun., 1979) found pollen zone IV assemblages in sidewall cores from 2,004 and 2,200 ft; these samples are from the interval dated as early Turonian by Petters (1976) and lie within the part of the section identified as pollen zone IV by Perry and others (1975). I have examined the calcareous nannofossils from these two cores. The sample from 2,004 ft is Turonian in age and contains Corollithion achylosum and Eiffellithus eximius as well as Biscutum blackii, Chiastozygus cuneatus, C. plicatus, Corollithion signum, Cretarhabdus conicus, C. crenulatus, Eiffellithus turriseiffeli, Gartnerago segmentatum, G. striatum, Lithastrinus floralis, L. grillii, Microrhabdulus decoratus, Parhabdolithus angustus, $P$. embergeri, $P$. splendens, Prediscosphaera cretacea, Vagalapilla matalosa, Watznaueria barnesae, Zygodiscus acanthus, $Z$. diplogrammus, and $Z$. fibuliformis.

The nannofossil assemblage from $2,200 \mathrm{ft}$ is almost identical with the one from $2,004 \mathrm{ft}$ except for the absence of Eiffellithus eximius and the presence of Lithraphidites acutum. I interpret this assemblage to be early Turonian in age. Lithraphidites acutum Verbeek and Manivit is a newly described species that ranges from middle Cenomanian to middle Turonian (Manivit and others, 1977, pl. 1, figs. 7, 8). This form was previously included in the stratigraphically older $L$. alatus Thierstein, a species once thought to be restricted to Cenomanian and lowermost Turonian strata (Thierstein, 1976; compare Roth and Thierstein, 1972, pl. 3, figs. 1-8 and Thierstein 1974, pl. 3, figs. 5-11). Since the separation of $L$. acutum, $L$. alatus is reported to range from the upper Aptian to only the upper Cenomanian (Manivit and others, 1977), but its upper limit is not documented thoroughly yet, and it probably ranges into 
the lower Turonian. The last occurrence of $L$. acutum in the Turonian is not precisely known, as implied by the dashed line representing the upper part of its range in Manivit and others (1977, fig. 1). In figure 1 of Manivit and others (1977), I consider the Cenomanian-Turonian boundary to occur at the extinction of Rotalipora cushmani, not at the lower level they have shown; my interpretation does not significantly alter the age of the upper part of the range of $L$. acutum portrayed in their figure. The lower Turonian sidewall core from $2,200 \mathrm{ft}$ in the Island Beach well is at or near the CenomanianTuronian boundary and the base of the Woodbridge Clay Member (Petters, 1976).

In the Toms River well, Doyle (1969b; oral commun. 1981) examined spores and pollen from sidewall cores and found floras typical of the Woodbridge Clay Member in samples from 1,298 to 1,300 and 1,369 to $1,371 \mathrm{ft}$, and a somewhat older assemblage at 1,437 to $1,439 \mathrm{ft}$. All these samples are above $1,440 \mathrm{ft}$, where Petters (1976) identified the Rotalipora extinction and the Cenomanian-Turonian boundary. I have examined calcareous nannofossils in six sidewall cores from the section immediately above the Cenomanian-Turonian boundary, and the assemblages are similar to those described above in the Island Beach well samples. The upper four samples, from 1,323 to $1,393 \mathrm{ft}$, contain Corollithion achylosum and Eiffellithus eximius and are of Turonian age. The lower two samples contain Lithraphidites acutum, Podorhabdus albianus, and Parhabdolithus asper, but not Eiffellithus eximius, and they are early Turonian in age. Biostratigraphic evidence from planktic foraminifers (Petters, 1976) and calcareous nannofossils in the Island Beach and Toms River wells shows that the pollen zone IV (Complexiopollis-Atlantopollis assemblage zone) floras are early Turonian in age.

In the Fripp Island, S.C., well, a pollen zone IV assemblage resembling that found in the Woodbridge Clay and Sayreville Sand Members of New Jersey has been identified by R. A. Christopher (unpub. data, 1977) in cuttings samples from 3,097 to 3,107 and 3,127 to $3,137 \mathrm{ft}$. Calcareous nannofossils in individual rock chips from 3,057 to $3,067,3,097$ to 3,107 , and 3,137 to $3,147 \mathrm{ft}$ contain Eiffellithus eximius and Corrollithion achylosum and are of Turonian Age.

In the Clubhouse Crossroads corehole 1, also in South Carolina, a pollen zone IV flora is present in a $62-\mathrm{ft}$ section from 2,342.3 to $2,404.8 \mathrm{ft}$ (R. A. Christopher, unpub. data, 1976; Hazel and others, 1977). I have examined 67 samples from this interval; 33 of them are fossiliferous and contain calcareous nannofossil assemblages of early Turonian age that included such species as Ahmuellerella octoradiata, Corollithion achylosum, Cruciellipsis chiastia, Lithraphidites acutum, Parhabdolithus asper, and Podorhabdus albianus.

On the Atlantic continental margin, therefore, spore and pollen assemblages of pollen zone IV are found with Turonian calcareous nannofossils in the Island Beach and Toms River wells in New Jersey, in the Fripp Island well and the Clubhouse Crossroads corehole 1 in South Carolina, and in the COST GE-1 well off Georgia.

Finally, in the corehole beneath the Gulf Coastal Plain at Dallas, Tex. (fig. 3), pollen zone IV assemblages are present in the middle and upper parts of the Britton Formation (208.9 to $438.6 \mathrm{ft}$ ) and possibly in the lowermost part of the overlying Arcadia Park Formation, both of the Eagle Ford Group (Socony-Mobil Field Research Lab Corehole No. 16; Brown and Pierce, 1962; Pessagno, 1969; Christopher, in press). The zone IV spores and pollen are found in a section of the core that has been dated by Pessagno $(1969$, pl. 9) by means of planktic foraminifers and determined to include mainly strata of late Cenomanian Age (Britton Formation) separated by a disconformity from a short sequence of late Turonian Age (uppermost part of Britton Formation and lower part of Arcadia Park Formation). Planktic foraminifers are relatively sparse in the core, however, and Cenomanian rotaliporid marker species are represented by a single occurrence of Rotalipora cuhsmani at $444 \mathrm{ft}$ (Pessagno, 1969, pl. 39b), just below the base of pollen zone IV delineated by Christopher (in press).

On the other hand, recent unpublished studies by J. D. Powell of Grand Junction, Colo. (oral and written communs., 1980; fig. 3, this report), on the planktic foraminifers, ammonites, and inoceramids collected from outcrops near the Dallas corehole site have shown that the upper $15 \mathrm{ft}$ of the Britton Formation and possibly the lower $30 \mathrm{ft}$ of the Arcadia Park Formation actually represent the lower Turonian Mytiloides "labiatus" zone (Kauffman and others, 1977) and that the underlying approximately $200 \mathrm{ft}$ of the middle and upper parts of the Britton Formation represents the Sciponoceras gracile zone interpreted by him to be of latest Cenomanian Age. Christopher (in press) has suggested that pollen zone IV in the Dallas core coincides with the Sciponoceras gracile zone and with the base of the Mytiloides "labiatus" zone outlined by Powell in outcrop.

In summary, pollen zone IV is present in a part of the Dallas core (middle and upper parts of Britton Formation and lower part of Arcadia Park Formation) that has been dated as late Cenomanian and late Turonian by means of planktic foraminifers, whereas, in nearby outcrops, this interval has been dated as late Cenomanian and early Turonian by means of planktic foraminifers, ammonites, and inoceramids. 
I have studied the Dallas core (fig. 3), and nannofossils are common to abundant and well preserved except for an interval in the upper part of the Britton Formation where the assemblages are sparse. Eiffellithus eximius first appears at $210.1 \mathrm{ft}$, just below the top of the Britton Formation and ranges up through the Arcadia Park Formation; its co-occurrence with Corollithion achylosum indicates a Turonian age for this interval. The basal beds of this sequence are in the upper part of pollen zone IV and are equivalent to Turonian strata containing pollen zone IV assemblages that have been already described from the Island Beach well, the Toms River well, and the COST GE-1 well on the Atlantic margin. The middle and upper part of the Britton Formation from about $224.7 \mathrm{ft}$ down to the base of pollen zone IV ( $438.6 \mathrm{ft})$ contains a calcareous nannofossil assemblage that includes the following species: Ahmuellerella octoradiata, Cruciellipsis chiastia, Lithraphidites acutum, Microrhabdulus belgicus, Parhabdolithus asper, and Podorhabdus albianus. Similar assemblages have been found in the Toms River, Island Beach, and Clubhouse Crossroads wells. The upper range of Cruciellipsis chiastia has been extended recently from the Cenomanian into the lower Turonian (Barrier, 1980), and the other species all occur in the Turonian.

The studies of the Britton and Arcadia Park Formations in Dallas, Tex., indicate to me that pollen zone IV represents: (a) the lower Turonian, found in the middle and upper part of the Britton Formation within the Sciponoceras gracile zone and containing Corollithion achylosum and Lithraphidites acutum; (b) the lower Turonian, found in the uppermost part of the Britton Formation and lower part of the Arcadia Park Formation within the Mytiloides labiatus zone, where Corollithion achylosum and Eiffellithus eximius are present, but not Lithraphidites acutum.

The spore and pollen flora reported by Christopher (in press) from the middle and upper parts of the Arcadia Park Formation and the lower part of the Austin Group in the Dallas core contains elements of both pollen zone IV and the younger pollen zone V-A ( = zone V of Sirkin, 1974; = Complexiopollis exigua-Santalacites minor assemblage zone of Christopher, 1979). Calcareous nannofossils from the same interval in the core range in age from Turonian (middle and upper part of the Arcadia Park Formation) to Coniacian (Austin Group). We will see in subsequent discussions that similar post-pollen zone IV-pre-pollen zone V floras have also been identified in some wells on the southeastern Atlantic margin (R. A. Christopher, unpub. data, 1977-1979).

\section{FRIPP ISLAND WELL, SOUTH CAROLINA}

The Fripp Island well (table 1, fig. 1) is a key well for interpreting the Upper Cretaceous stratigraphy in South Carolina. I have studied the section in detail, using calcareous nannofossils; in all, I have examined 279 cuttings samples at 94 levels in the approximately 1,700-ft Upper Cretaceous interval. Cuttings were collected over 10-ft intervals, and individual rock chips representative of each lithologic unit in a sample were examined for calcareous nannofossils. There is a $263-\mathrm{ft}$ sampling gap in the Campanian part of the section. The biostratigraphy of the well (fig. 4) is based on the ranges of the following species: Micula mura $(1,507 \mathrm{ft})$; Tetralithus aculeus $(1,507-1,970 \mathrm{ft}) ; \quad T$. trifidus (1,527-1,970 ft); Broinsonia parca $(1,527-2,427)$; Eiffellithus eximius $(1,808-3,147 \mathrm{ft}$, lowest sample); Lithastrinus grillii (2,263-2,867 ft); Chiastozygus cuneatus $(2,427-3,007 \mathrm{ft}) ;$ Lithastrinus floralis $(2,457-3,147 \mathrm{ft}$, lowest sample); Marthasterites furcatus $(2,457-2,857 \mathrm{ft})$; and Corollithion achylosum $(3,057-3,147 \mathrm{ft}$, lowest sample).

The Tertiary-Cretaceous contact is at $1,437 \mathrm{ft}$, and the Maestrichtian-Campanian boundary is at $1,808 \mathrm{ft}$. The top of the Santonian is at 2,427 ft, and Santonian and Santonian-Coniacian cuttings are consistently present down to $2,867 \mathrm{ft}$; the samples from $2,637 \mathrm{ft}$ down to the top of the Turonian at $3,057 \mathrm{ft}$ are dominated by coarse quartz sand, and from 2,877 ft, the cuttings are predominantly Campanian cavings. The unfossiliferous sand from 2,637 to $3,057 \mathrm{ft}$ may in fact be Coniacian in age, but because I could not distinguish the boundary between the Santonian and Coniacian Stages, I have designated the entire interval from 2,427 to $3,057 \mathrm{ft}$ as Santonian-Coniacian.

Near the bottom of the Fripp Island well, a Turonian calcareous nannofossil assemblage is present in three samples $(3,057$ to $3,067,3,097$ to 3,107 , and 3,137 to $3,147 \mathrm{ft}$ ) that include Ahmuellerella octoradiata, Corollithion achylosum, C. exiguum, Eiffellithus eximius, and Lithastrinus floralis. Two samples from within this interval $(3,097$ to 3,107 and 3,127 to $3,137 \mathrm{ft})$ contain a flora indicative of pollen zone IV (R. A. Christopher, unpub. data, 1977). A sample from 3,117 to $3,127 \mathrm{ft}$ contains a planktic foraminiferal assemblage dated as Turonian or Coniacian but not older than Turonian, and rotaliporid species indicative of the Cenomanian are absent (C. C. Smith, unpub. data, 1977). Samples were not available from the lowermost $21 \mathrm{ft}$ of the section, and the well did not penetrate crystalline basement rocks (Gohn and others, 1978a).

There is little disagreement between my interpretation of the upper part of the Fripp Island section and 
Well No. 13, Fripp Island, S.C.

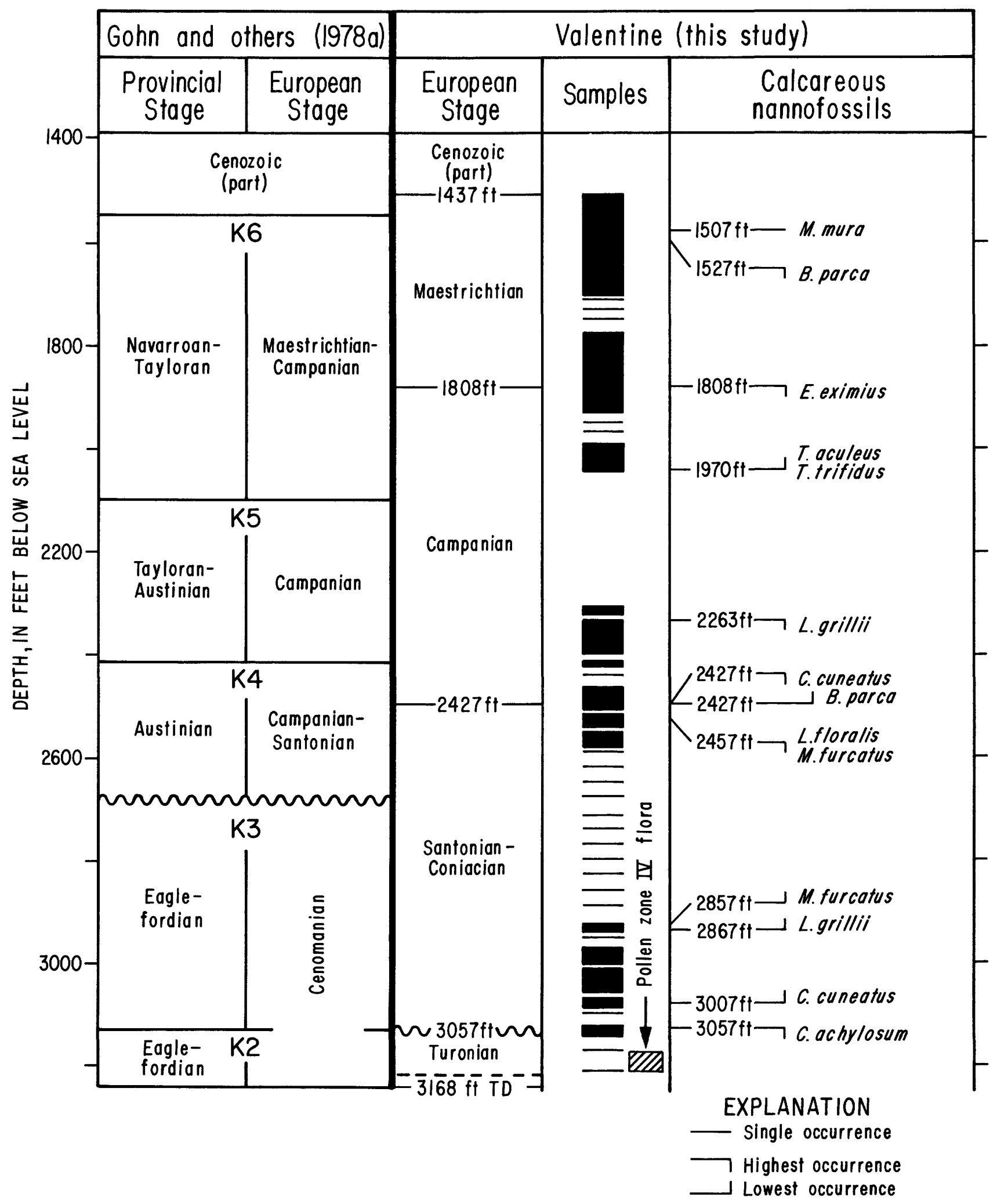

FiguRE 4. -Stratigraphic interpretations of the Fripp Island well, South Carolina; Gohn and others (1978a) compared with Valentine (this study, based on calcareous nannofossils). In sample column, blacked-in areas indicate complete sequence of samples studied. Pollen zone IV flora, indicated by ruled area, identified by R. A. Christopher (U.S. Geological Survey). Depth scale is relative to sea level; stratigraphic boundaries and fossil occurrences are given in original depths (for depth below sea level, subtract $5 \mathrm{ft}$ ). 
that of Gohn and others (1978a). I place the TertiaryCretaceous contact somewhat higher (at $1,437 \mathrm{ft}$ ) than do Gohn and others on the basis of the first appearance of a mixed assemblage of Cretaceous and Paleocene nannofossils. In the lower part of the well, Gohn and others (1978a) interpreted their units K2 and K3 to be Cenomanian in age and postulated a major hiatus above unit K3 that represents Coniacian and Turonian time. In contrast, I believe these strata to be younger, and I interpret their unit K3 to represent beds of SantonianConiacian Age and unit K2 to be Turonian in age.

\section{PARRIS ISLAND NO. 2 WELL, SOUTH GAROLINA}

The Parris Island No. 2 well is only 11 miles west of the Fripp Island well (table 1, fig. 1) and is useful for comparing the stratigraphic schemes of Gohn and others $(1978 \mathrm{a}, 1980)$ with those of Brown and others (1979). This comparison and the independent dating, by means of calcareous nannofossils, of the units of Gohn and others (1978a) at Fripp Island are important for determining the subsurface stratigraphy of the region. Gohn and others (1978a) used paleontological analyses and electric logs to date and correlate the Parris Island and Fripp Island wells. The basis for the interpretation of the Parris Island well by Brown and others (1979) is not given but, as mentioned above, presumably includes lithologic characteristics and the occurrences of key species of ostracodes and foraminifers. A comparison of the results of these two studies is shown in figure 5 .

The stratigraphic interpretations of the Parris Island well by Gohn and others (1978a) and Brown and others (1979) do not differ significantly in the upper part of the sections, except that Brown and others placed the Tertiary-Cretaceous contact about $180 \mathrm{ft}$ shallower than did Gohn and others. However, differences in interpretation exist at lower levels, for example, from 2,528 to about 2,650 ft, where unit D (Eaglefordian; Turonianupper Cenomanian) of Brown and others (1979) overlaps the lower part of an ostensibly younger unit K4 (Austinian; lower Campanian-Santonian) of Gohn and others (1978a). And although both of these studies recognized coincident stratigraphic boundaries lower in the well (at 3,144 and 3,256 ft), Brown and others (1979) assigned these strata to their unit E (Woodbinian; Cenomanian) and unit F (Washitan-Fredericksburgian; lower Cenomanian-Albian), whereas Gohn and others (1978a, 1980) considered the same beds to be younger and placed them, respectively, in their unit K2 (middle Eaglefordian; upper Cenomanian) and unit K1 (Upper? Cretaceous).

I have not studied any samples from Parris Island, and paleontological analyses are sparse in the lower part of the well, as only three samples are shown by Gohn and others (1978a, sheet 2) to have been studied between $2,350 \mathrm{ft}$ and the bottom of the well at $3,454 \mathrm{ft}$. Gohn and others (1978a) showed that in the upper part of the Parris Island to Fripp Island section units K4, K5, and $\mathrm{K} 6$ dip eastward, whereas the older units (K1, K2, and K3) dip westward. However, I interpret the electric logs illustrated by Gohn and others (1978a) to show that the upper units (K4, K5, and $\mathrm{K} 6$ ) also dip gently westward, and I have reevaluated the stratigraphy of the Parris Island well by using the electric logs and applying the stratigraphy that I established by means of calcareous nannofossils for the nearby Fripp Island well. Figure 5 shows my assessment of the Parris Island stratigraphy and its correlation with that of Fripp Island. The strata in the lower part of the well are younger than previous authors have indicated. The beds attributed by Brown and others (1979) to their unit D (Eaglefordian; Turonian-upper Cenomanian) and unit E (Woodbinian; Cenomanian) and by Gohn and others (1978a) to their units K2 and K3 (middle Eaglefordian; upper Cenomanian) are now shown to represent the SantonianConiacian and Turonian stages. The age of the lower 200 $\mathrm{ft}$ of strata drilled at Parris Island, unit $\mathrm{F}$ of Brown and others (1979) and unit K1 of Gohn and others (1978a) is unknown at present.

\section{CLUBHOUSE CROSSROADS COREHOLE 1, SOUTH CAROLINA}

The Clubhouse Crossroads corehole 1 is on the northern flank of the Southeast Georgia Embayment, 42 miles north of the Parris Island and Fripp Island wells (table 1, fig. 1). The lithology and paleontology of the core has been extensively studied (Gohn and others, 1977; Hazel and others, 1977), and significantly, both Gohn and others (1978a) and Brown and others (1979) have incorporated this corehole into their respective stratigraphic frameworks (fig. 6). Their interpretations are coincident down to the base of the Austinian Stage. At that level, Gohn and others (1978a) indicated the presence of a major disconformity between their units $\mathrm{K} 4$ and $\mathrm{K} 3$; below the hiatus, they assigned the entire interval down to the basalt in the bottom of the hole to units K3 and K2 (middle Eaglefordian; upper Cenomanian) and $\mathrm{K} 1$ (Upper? Cretaceous in Gohn and others, 1980). On the other hand, Brown and others (1979) interpreted this same interval to inchude strata of their unit D (Eaglefordian; Turonian-upper Cenomanian) separated by a hiatus representing unit $\mathrm{E}$ (Woodbinian; Cenomanian) from the underlying rocks of unit $F$ (WashitanFredericksburgian; lower Cenomanian-Albian). Gohn and others (1978a) and Brown and others (1979), therefore, did not recognize the same hiatus in the lower part of this section and also disagreed on the age of the beds in the lower $\sim 200 \mathrm{ft}$ of the corehole. 
Well No. 12 Parris Island,S.C.

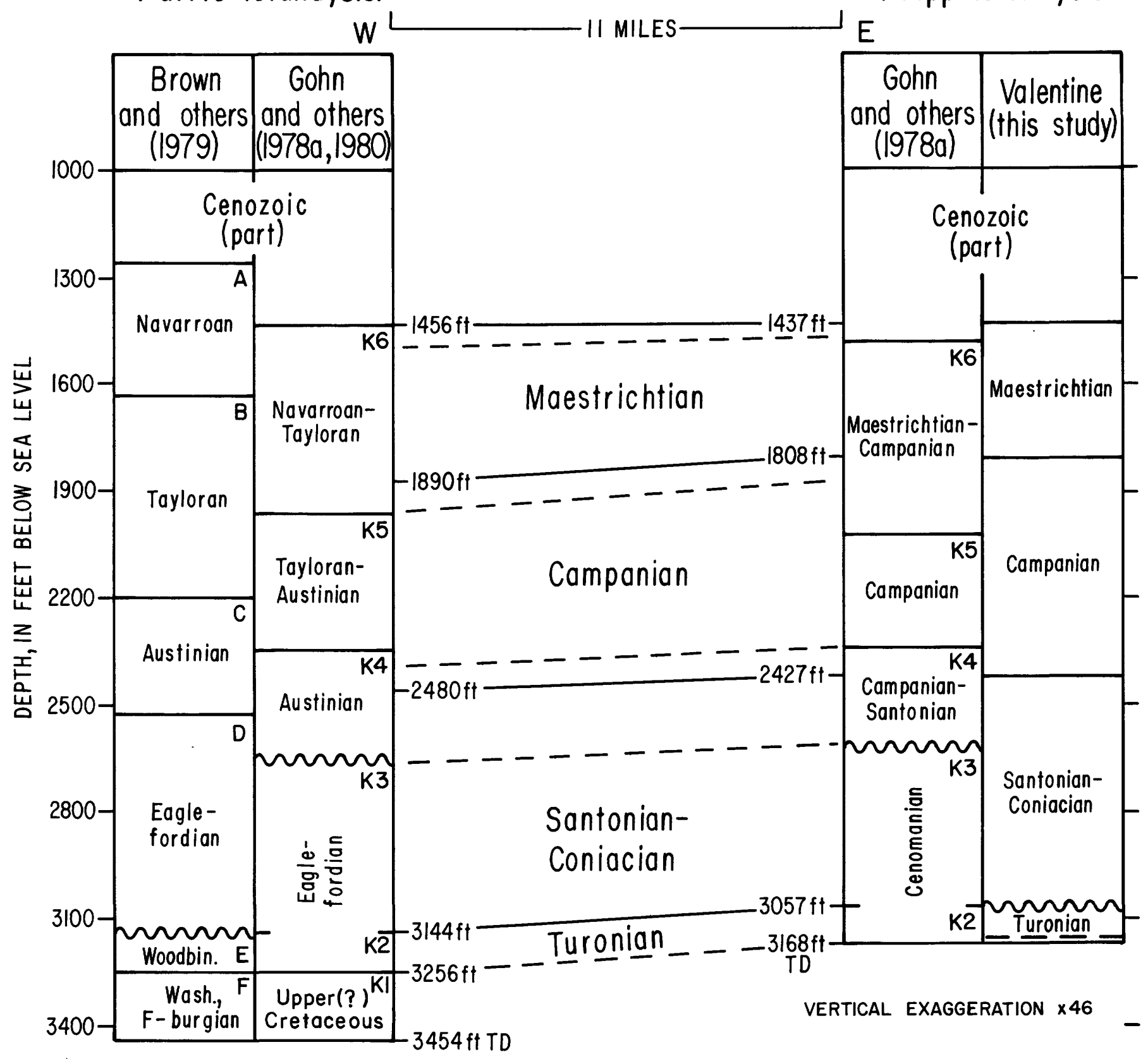

FIgURE 5. - Stratigraphic correlation of the Parris Island No. 2 and the Fripp Island wells, South Carolina, showing stratigraphic interpretations of Gohn and others (1978a, 1980), Brown and others (1979), and Valentine (this study). The stratigraphic units of Gohn and others (1978a, 1980) are expressed as their European-stage equivalents in the Fripp Island well and as their Gulf Coast-stage equivalents in the Parris Island well. Fredericksburgian is abbreviated F-burgian; Washitan, Wash.; and Woodbinian, Woodbin. Dashed lines are electric-log correlations. Depth scale is relative to sea level; stratigraphic boundaries are given in original depths (for depth below sea level, subtract $5 \mathrm{ft}$ for the Fripp Island well and $18 \mathrm{ft}$ for the Parris Island well). 
Well No. 16, Clubhouse Crossroads, S.C.

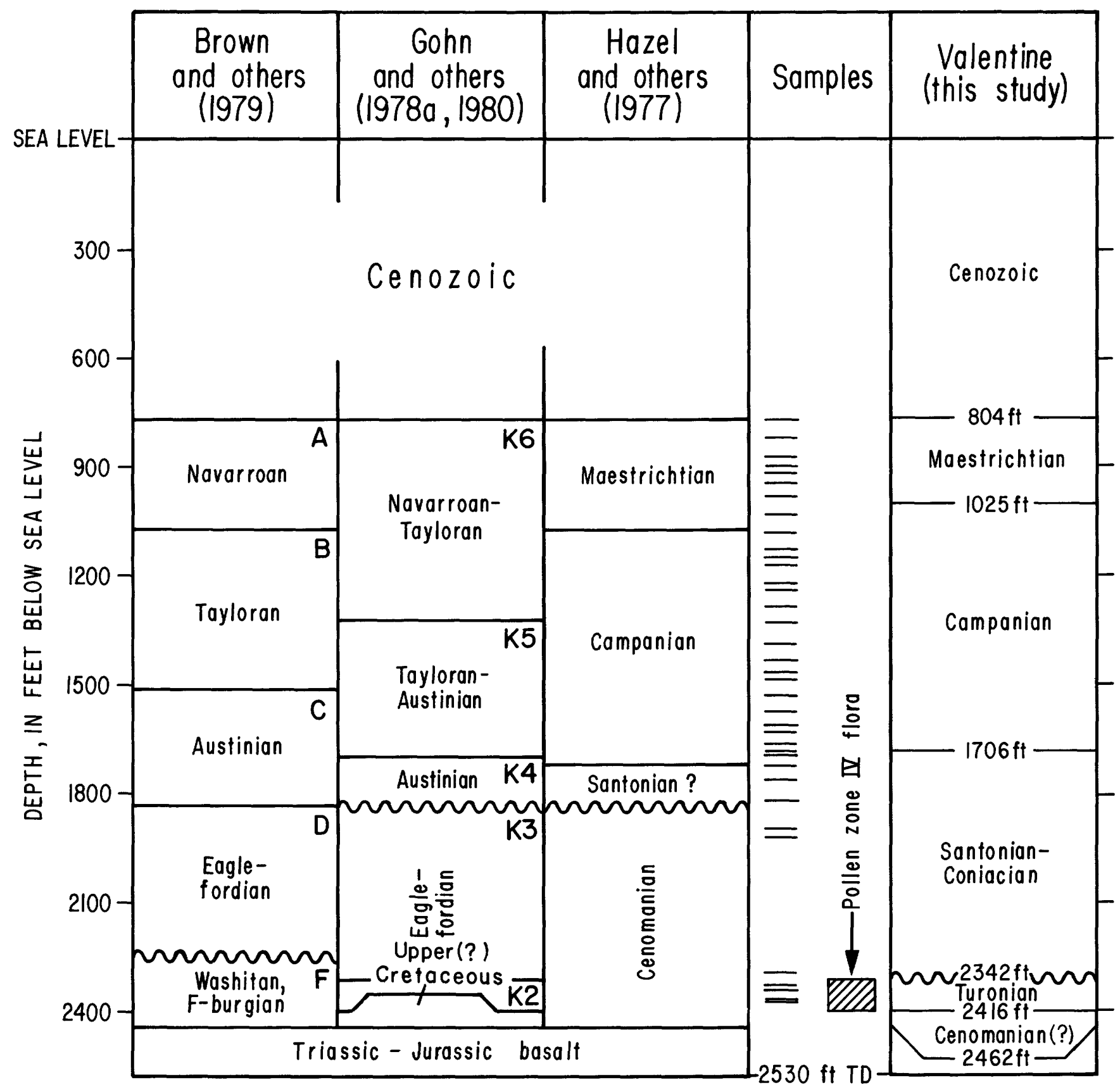

FIgURE 6. - Stratigraphic interpretations of the Clubhouse Crossroads corehole 1, South Carolina, of Hazel and others (1977), Gohn and others (1978a, 1980), Brown and others (1979), and Valentine (this study). Fredericksburgian is abbreviated F-burg. Samples shown were, for the most part, discussed by Hazel and others (1977). Pollen zone IV flora, represented by ruled area, identified by R. A. Christopher (USGS). Depth scale is relative to sea level; stratigraphic boundaries are given in original depths (for depth below sea level, subtract $23 \mathrm{ft}$ ). 
Hazel and others (1977), using planktic foraminifers, have shown that the Tertiary-Maestrichtian contact is at approximately $804 \mathrm{ft}$, and they reported Maestrichtian foraminifers from $1,025 \mathrm{ft}$, somewhat above a Campanian calcareous nannofossil flora at $1,050 \mathrm{ft}$ (Hattner and Wise, 1979). Campanian strata extend down to approximately $1,706 \mathrm{ft}$, where spore and pollen assemblages have been reported (Hazel and others, 1977) that are typical of the Magothy Formation of New Jersey.

The beds from 1,706 to $2,342 \mathrm{ft}$ are almost barren of fossils, and spore and pollen assemblages are present only in the upper $200 \mathrm{ft}$ of the interval. The Magothy flora is present from 1,706 to $1,804 \mathrm{ft}$; from 1,804 to $1,906 \mathrm{ft}$, a flora is present that is characteristic of the upper member (South Amboy Fire Clay Member) of the Raritan Formation of New Jersey (Hazel and others, 1977). The Magothy and the South Amboy spore and pollen assemblages constitute the tripartite pollen zone V of Christopher (1977, 1979, and in press). This stratigraphic interval is chiefly Santonian in age, but it also includes strata of earliest Campanian and possibly Coniacian Age (R. A. Christopher, oral commun., 1979). I have examined two samples from this interval for calcareous nannofossils. The sample from $1,752 \mathrm{ft}$ contains a rich Santonian assemblage, but nannofossils are rare in the sample from $1,943 \mathrm{ft}$, and its age is equivocal; the presence of Eiffellithus eximius, Tetralithus obscurus, and Lithastrinus grillii point to a Turonian Age or younger, possibly Coniacian. Few planktic foraminifers have been observed in the interval from 1,706 to $2,342 \mathrm{ft}$. Two samples $(1,922.5$ and $2,308.8 \mathrm{ft})$ examined by C. C. Smith (unpub. data, 1976) each contained a single species (Globigerinelloides caseyi and $G$. sp. cf. G. caseyi, respectively) and were attributed to the Cenomanian, partly because several samples from below $2,308.8 \mathrm{ft}$ were dated as Cenomanian. G. caseyi, however, is not restricted to the Cenomanian; it has been reported from the upper Cenomanian and lower and middle Turonian of Kansas and Colorado (Eicher and Worstell, 1970), and the highest occurrence of this species is also considered to be diagnostic of lower Turonian strata beneath the Scotian Shelf of Canada (Ascoli, 1976). Furthermore, these strata from 1,706 to $2,342 \mathrm{ft}$ are characterized by sand and silt, and Gohn and others (1978a, sheet 2) have shown this interval, units K3 (upper Cenomanian) and K4 (Santonian-lower Campanian) to be correlative with a lithologically similar sequence in the Fripp Island well that I have determined to be Santonian-Coniacian in age.

Lower in the Clubhouse Crossroads core, a spore and pollen flora characteristic of pollen zone IV and the Woodbridge Clay Member of the Raritan Formation (New Jersey) is present from $2,342.3$ to $2,404.8 \mathrm{ft}$ (R. A.
Christopher, unpub. data, 1976; Hazel and others, 1977). Samples from these beds $(2,364.4,2,365.4,2,369.4$, $2,373.7$, and $2,399.2 \mathrm{ft}$ ) contain planktic foraminifers that have been interpreted as late Cenomanian in age, although Cenomanian rotaliporids are absent (C. C. Smith, unpub. data, 1976; Hazel and others, 1977). These planktic assemblages are composed of one to three species, Guembelitria harrisi, Hedbergella brittonensis, and Heterohelix moremani. The age determination is based chiefly on the presence of Guembelitria harrisi, which is present in all samples; however, the range of this species is not precisely known, and in Colorado, Wyoming, and South Dakota it has been reported to range higher than the rotaliporids and therefore into the Turonian (Eicher and Worstell, 1970). Additional samples from this interval $(2,367.5$, $2,370.5$, and 2,396 ft) have yielded assemblages of planktic foraminfers containing only two species, Guembelitria harrisi and Heterohelix moremani (C. W. Poag, unpub. data, 1981).

Calcareous nannofossils from the Cretaceous of the Clubhouse Crossroads core have been studied by Hattner and Wise (1980). They examined four samples from the pollen zone IV interval and reported the presence of Ahmuellerella octoradiata, Lithraphidites acutum, and $L$. alatus in an assemblage from $2,372 \mathrm{ft}$, which they dated as Cenomanian. The other samples are barren or contain a nondiagnostic flora.

I have also studied the calcareous nannofossils from pollen zone IV strata in the core; 33 of 67 samples examined in the 62-ft interval are fossiliferous. The range of biostratigraphically important species are: Ahmuellerella octoradiata (2,370-2,407 ft); Corollithion achylosum (2,363-2,407 ft); Cruciellipsis chiastia (2,364.5-2,406 ft); Eiffellithus eximius (rare, 2,364 ft); Lithraphidites acutum (2,372.5-2,406 ft); Lithraphidites alatus (rare, 2,394 ft); Microhabdulus belgicus (rare, 2,373 and 2,406 ft); Micula staurophora (2,370-2,407 ft); Parhabdolithus asper (2,363-2,406 ft); and Podorhabdus albianus (2,364-2,406 ft). I interpret this interval to be early Turonian in age. These beds are units K2 of Gohn and others (1978a), and they have shown the beds to be coeval with K2 in the Fripp Island well that also contains a pollen zone IV flora and in which I have identified Turonian calcareous nannofossil assemblages. Brown and others (1979) indicated that their unit $\mathbf{E}$ is missing from the Clubhouse Crossroads section, but the evidence presented above and the stratigraphy of the Parris Island well (fig. 5) suggest that it is present and that it is probably coincident here with unit K2 of Gohn and others (1978a).

The strata in the core between $\sim 2,416 \mathrm{ft}$ and the basalt encountered at about $2,462 \mathrm{ft}$ are unfossiliferous, and I regard them, with reservation, to be Cenomanian 
in age. In subsequent drilling, approximately $3 \mathrm{mi}$ from Clubhouse Crossroads corehole 1 , the basalt was penetrated to reveal clastic red beds of Late Triassic to Early Jurassic age (Gohn and others, 1978b).

\section{PENNY ROYAL AND MYRTLE BEACH WELLS, SOUTH} CAROLINA, CALABASH WELL, NORTH CAROLINA

The Penny Royal, Myrtle Beach, and Calabash wells are on a transect extending from approximately $60 \mathrm{mi}$ south of the Cape Fear Arch northeastward to its crest (fig. 1). The wells have been studied by Gohn and others (1978a) and by Brown and others (1979). Gohn and others (1978a) did not differentiate their units K5 and $\mathrm{K} 6$ in these three northern wells, and I have attempted to separate the two units by using the electric logs published by the authors. On the same basis, I have raised the top of their unit $\mathrm{K} 3$ in the Calabash well.

The paleontological analyses of the wells by C. C. Smith and R. A. Christopher (unpub. data, 1977, 1978) are the basis for the age determinations of Gohn and others (1978a) and for my own interpretations, and sample levels are shown in figure 7. In the Penny Royal well, the Maestrichtian-Campanian boundary has been drawn at $\sim 550 \mathrm{ft}$, between two cuttings samples (490-510 and 590-610 ft) containing diagnostic planktic foraminifers and calcareous nannofossils. At Myrtle Beach, Maestrichtian foraminifers are present in the upper part of the well, and Santonian-Coniacian(?) spore and pollen assemblages of pollen zone $\mathrm{V}$ are present from $953 \mathrm{ft}$ to at least 1,242 ft. In the Calabash well, the CampanianSantonian boundary is at about $750 \mathrm{ft}$, between two samples (690-700 and 800-810 ft) containing spores and pollen. Santonian-Coniacian(?) floras are present in all the underlying samples down to $1,170 \mathrm{ft}$.

The lower part of the Santonian-Coniacian interval, as I have delineated it in the Myrtle Beach and Calabash wells (fig. 7) is interpreted by Gohn and others (1978a, unit K3) and Brown and others (1979, unit D) to be of Turonian or late Cenomanian age. The age of the strata below the last sample and above basement in the Calabash and Myrtle Beach wells is not known, but Brown and others (1979) indicated that the beds were as old as early Cenomanian and Albian, whereas Gohn and others (1978a) considered them to be late Cenomanian in age.

\section{GEORGIA GEOLOGICAL SURVEY WELLS, SOUTHEASTERN GEORGIA}

Georgia Geological Survey wells 719, 724, 876, 1197, and 1198 were drilled into the deepest part of the Southeast Georgia Embayment beneath the Coastal Plain (fig. 1). The top of the Cretaceous here lies $\sim 2,600$ $\mathrm{ft}$ below sea level, and it dips very gently seaward. Offshore, at the COST GE-1 site 88 miles to the east, where the Southeast Georgia Embayment is deepest, the Upper Cretaceous surface is $-3,450 \mathrm{ft}$ below sea level. In contrast to the Upper Cretaceous surface, the crystalline and metamorphic basement rocks are at $\sim 4,600 \mathrm{ft}$ beneath the Coastal Plain and dip more steeply seaward to $\sim 11,000 \mathrm{ft}$ at COST GE-1. The offshore section accommodates a sequence of Lower Cretaceous nonmarine and shallow marine clastic and carbonate rocks approximately $5,000 \mathrm{ft}$ thick that are absent, or at least very poorly represented, beneath the Georgia coast.

This series of five wells (fig. 8) has been studied, in part, by Marsalis (1970), Maher (1971), and Gohn and others (1980), and all five wells have been investigated by Brown and others (1979). A comparison of their interpretations of the younger strata shows generally good agreement, but their stage asssignments and terminology differ somewhat in the lower parts of the wells, where Marsalis (1970) and Maher (1971) use the terms Atkinson Formation and Comanchean Provincial Series for strata that are identified by the other authors as representing the Eaglefordian, Woodbinian, Washitan, and Fredericksburgian Stages. The relations already establiched between the stratigraphic units of Gohn and others (1978a) and Brown and others (1979) in the South Carolina subsurface are also evident in Georgia. Brown and others (1979) showed that strata representative of unit $E$ (Woodbinian) are present throughout the deep part of the Southeast Georgia Embayment but apparently are absent north of the Parris Island well in South Carolina. The inclusion of the interpretations of Marsalis (1970) and Maher (1971) provides an opportunity to compare the placement of the Atkinson Formation with regard to the stratigraphic units of Brown and others (1979) and Gohn and others (1980).

The GGS 724 and GGS 1198 wells have been documented paleontologically, using calcareous nannofossils, planktic foraminifers, and spores and pollen (C. C. Smith and R. A. Christopher, unpub. data, 1978). The upper part of the Maestrichtian section is barren in both wells, but the Maestrichtian-Campanian interval can be differentiated from underlying Santonian strata at $~ 3,750 \mathrm{ft}$ in GGS 1198 and at $\sim 3,900 \mathrm{ft}$ in GGS 724 . In both wells, the Campanian-Santonian boundary is near the boundary between units K5 and K4 of Gohn and others (1980) and the boundary between units B and C of Brown and others (1979). The Santonian-Coniacian interval is present in GGS 1198 down to $\sim 4,300 \mathrm{ft}$ and in GGS 724 down to $\sim 4,450 \mathrm{ft}$. The age of the upper part of this interval is comparable with age determinations made by Brown and others (1979) and Gohn and others (1980). However, the lower part of the SantonianConiacian in these two wells is equivalent to strata identified by Brown and others (1979) as unit D (Eagleford- 


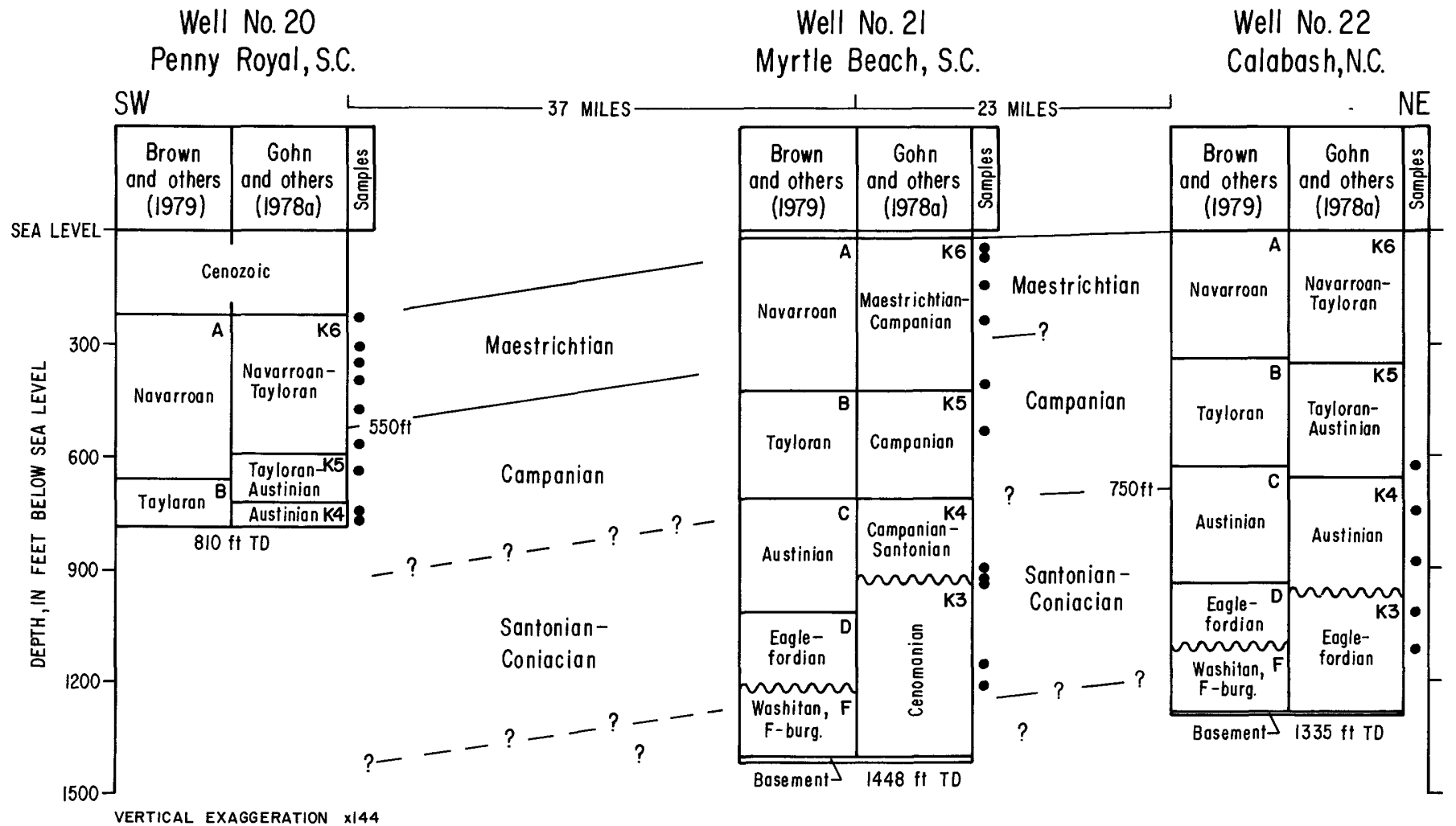

Figure 7. - Stratigraphic correlation of the Penny Royal and Myrtle Beach wells, South Carolina, and the Calabash well, North Carolina, based on the results of this study and showing stratigraphic interpretations of Gohn and others (1978a) and Brown and others (1979). Fredericksburgian is abbreviated F-burg. Samples shown were originally part of the study by Gohn and others (1978a). Depth scale is relative to sea level; stratigraphic boundaries are given in original depths (for depth below sea level, subtract $20 \mathrm{ft}$ for the Penny Royal well, $25 \mathrm{ft}$ for the Myrtle Beach well, and $48 \mathrm{ft}$ for the Calabash well).

ian; Turonian-upper Cenomanian), by Gohn and others (1980) as unit K2-3 (middle Eaglefordian; upper Cenomanian), and by Maher (1971) as the upper part of the Atkinson Formation.

In the GGS 1198 well, three samples $(4,340-4,370$, $4,500-4,530$, and $4,590-4,620 \mathrm{ft}$ ) from strata assigned to units $E$ and $F$ by Brown and others (1979) and units K2-3 by Gohn and others (1980) contain spore and pollen assemblages that represent pollen zone IV or a biostratigraphic interval between zone IV and the younger zone $\mathrm{V}$ of early Campanian-SantonianConiacian age (R. A. Christopher, unpub. data, 1978). I place these beds in the Turonian on the basis of the association of Turonian calcareous nannofossils with pollen zone IV assemblages in the COST GE-1, Fripp Island, Clubhouse Crossroads, Island Beach, and Toms River wells and in the Dallas, Tex. core. As mentioned above, Christopher (in press) has reported post-zone IV-pre-zone V spore and pollen floras from the middle and upper parts of the Arcadia Park Formation (Turonian Age) and the lower part of the Austin Group (Coniacian Age) in the Dallas core. In contrast, C. C. Smith (unpub. data, 1978) has reported the presence of foraminifers and nannofossils of Cenomanian Age in a sample from 4,530-4,560 ft in GGS 1198, but the nannofossil assemblage (from handpicked cuttings) has a decided Turonian aspect (Corollithion achylosum, Eiffellithus eximius, Lithraphidites alatus, Parhabdolithus asper, and Podorhabdus albianus). The foraminiferal assemblage from the same sample is composed of species that range across the Turonian-Cenomanian boundary, as well as many species that are restricted to Turonian and younger strata; rotaliporid marker species are absent. Guembelitria harrisi is present, but, as noted above, its range is not precisely known. Similarly, in GGS 724, two samples $(4,520$ to 4,540 and $4,630-4,640 \mathrm{ft}$ ) from the lower $100 \mathrm{ft}$ of the section contain spores and pollen characteristic of either pollen zone IV or a post-zone IV-pre-zone V interval, and I interpret them to be Turonian in age. A thin interval of somewhat older, undated strata may be present just above basement in these wells.

Brown and others (1979) and Gohn and others (1980) have also studied GGS 1197, and the relations among their stratigraphic units that have been recognized in other wells are also evident here. Few samples have 
been analyzed paleontologically from this well. Santonian and Coniacian(?) strata containing pollen zone $\mathrm{V}$ floras are present in samples from 3,640 to 3,650 and 3,830 to 3,840 ft (R. A. Christopher, unpub. data, 1979), and I have observed calcareous nannofossils of Santonian Age in samples from 3,800 to 3,810 and 4,000 to $4,010 \mathrm{ft}$. These beds are part of units $\mathrm{C}$ and $\mathrm{D}$ of Brown and others (1979) and units K3 and K4 of Gohn and others (1980). A single sample from 4,180 to 4,190 ft, examined by R. A. Christopher (unpub. data, 1979), contains a spore and pollen assemblage indicative of either pollen zone IV or a pre-zone V interval, similar to the floras observed in the strata at GGS 724 and GGS 1198 that I place in the Turonian.

The remaining two wells studied in this region, GGS 719 and GGS 876, provide a comparison of the stratigraphic interpretations of Marsalis (1970) and Brown and others (1979). In the upper parts of the wells, these authors' delineation of the Gulf Coast provincial stages is fairly consistent and also is in agreement with the work of both Maher (1971) and Brown and others (1979) on GGS 724. However, the stage assignment of the Atkinson Formation, as recognized in these three wells, varies considerably. The Atkinson Formation, as redefined by Applin (1955), is composed of an upper member of Eaglefordian Age and a lower member of Woodbinian Age. At GGS 719, Brown and others (1979) confined the Atkinson Formation, as delineated by Marsalis (1970), to unit D (Eaglefordian), whereas at GGS 876, Brown and others (1979) equated the Atkinson Formation with units D, E, and part of F (Eaglefordian, Woodbinian, and part of the Washitan-Fredericksburgian). At GGS 724, the strata assigned to the Atkinson Formation (Eaglefordian, Woodbinian) by Maher (1971) have been placed by Brown and others (1979) in units C (part), D, E, and F (part Austinian, Eaglefordian, Woodbinian, and Washitan-Fredericksburgian). Clearly, it is either very difficult to recognize and correlate the lithologic units in this part of the Southeast Georgia Embayment or the Atkinson Formation is diachronous within this small region of the basin. I interpret the upper part of the Atkinson Formation of Marsalis $(1970)$ in these wells to be Santonian-Coniacian in age and the lower part to be Turonian and perhaps older.

\section{WELLS IN THE AXIS OF THE SOUTHEAST GEORGIA EMBAYMENT}

The geologic section $B-B^{\prime}$ (fig. 9) through GGS 144, GGS 724, and COST GE-1 lies along the axis of the Southeast Georgia Embayment (fig. 1). The stratigraphy at GGS 724 beneath the Coastal Plain and at COST GE-1 beneath the Outer Continental Shelf has been discussed above. GGS 144 was drilled into the shallow western part of the Southeast Georgia Embayment. The Upper-Cretaceous section is twice as thick at GGS 724, which was drilled into the deep part of the basin onshore, as it is at GGS 144, whereas Tertiary strata are equally thick in both wells. Studies of GGS 144 by Applin (1955) and Applin and Applin (1967) revealed that the Upper Cretaceous section is about $900 \mathrm{ft}$ thick and that Navarroan strata are absent. The absence of the Navarroan Stage in this well and to the west on the Suwannee Saddle and in part of the Southwest Georgia Embayment has been interpreted as being due to nondeposition in an uplifted area (Applin and Applin, $1967)$ or to post-Cretaceous erosion (Toulmin, 1955). Tayloran and Austinian rocks are present in GGS 144, as shown by both Applin and Applin (1967) and Brown and others (1979).

Lower in the well, the Atkinson Formation has been divided into an upper member of Eaglefordian Age and a lower member of Woodbinian Age by Applin (1955) and Applin and Applin (1967); Brown and others (1979) interpreted this part of the section similarly. Applin (1955) discovered a foraminifer assemblage, the "Barlow fauna," in a core (3,709-3,719 ft) from the lower member of the Atkinson Formation in GGS 144. The "Barlow fauna" contains the planktonic foraminifer Rotalipora cushmani, and Hazel (1969) concluded that the fauna is late Cenomanian in age and that therefore at least part of the lower member of the Atkinson Formation is of Eaglefordian rather than Woodbinian Age. The distinctive "Barlow fauna" is present in other wells in Georgia, Alabama, and Florida to the west and south of GGS 144 (Applin, 1955; Applin and Applin, 1967), but it has never been reported from wells drilled into the southeast Georgia Embayment proper or on the Cape Fear Arch to the northwest.

Cenomanian strata have not yet been recognized at GGS 724, but offshore at COST GE-1 the Cenomanian may be represented by a thin unfossiliferous interval between rocks of Turonian and Albian Age. Turonian strata at COST GE-1 contain a pollen zone IV flora; I interpret Turonian strata to be present also at the base of GGS 724 in unit K2 (middle Eaglefordian; upper Cenomanian) of Gohn and others (1980), where a spore and pollen flora indicative of pollen zone IV or pre-zone $\mathrm{V}$ has been reported (R. A. Christopher, unpub. data, 1978).

The pre-Cretaceous basement dips seaward along the section shown in figure 9. Beneath the Coastal Plain, the basement is overlain unconformably by a thin (up to $150-\mathrm{ft}$ ) interval of unfossiliferous strata that is possibly Late Cretaceous in age. In contrast, a thick $(\sim 7,500 \mathrm{ft})$ sequence of Early Cretaceous and older sedimentary and metasedimentary rocks is present beneath the Outer Continental Shelf; these rocks extend farther 


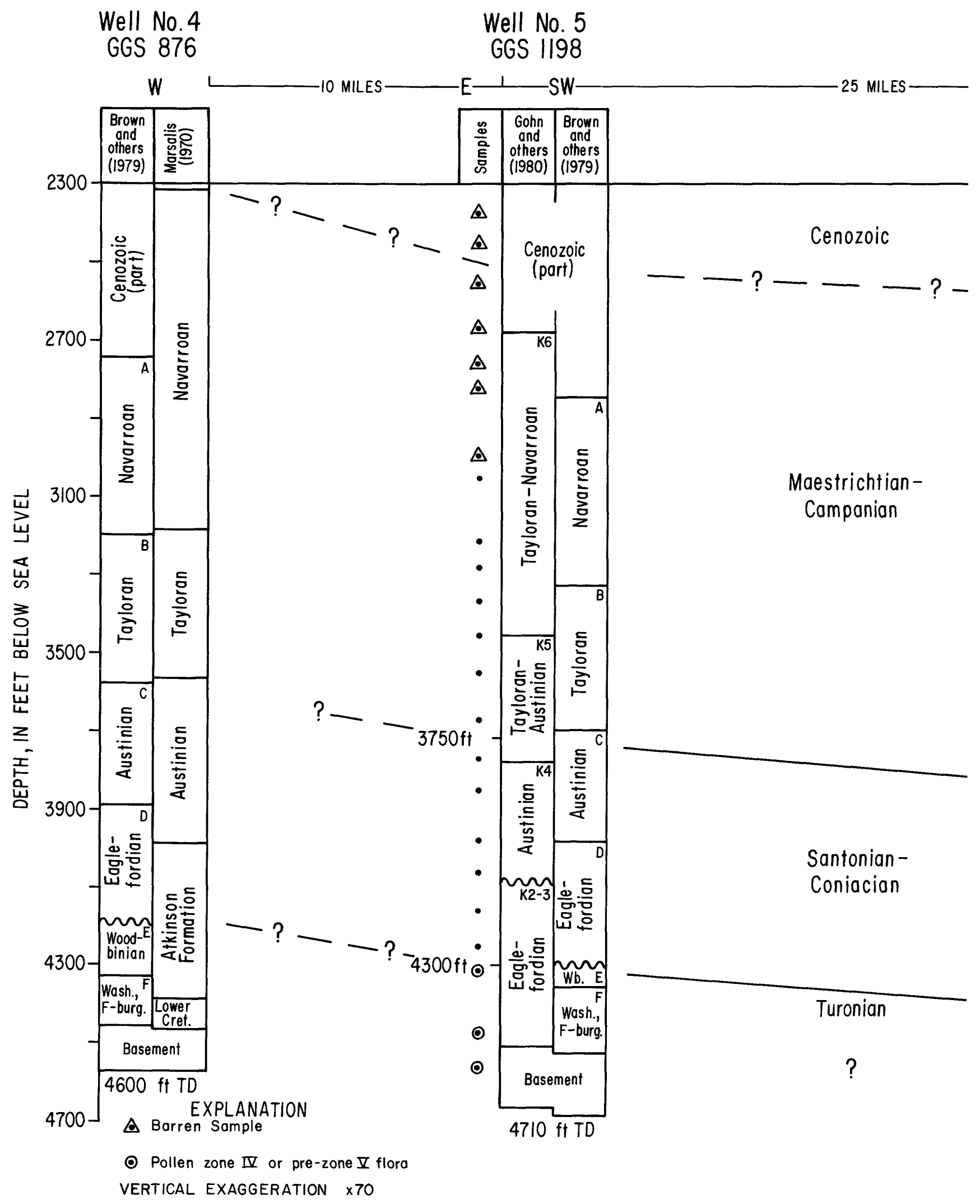

FIGURE 8. -Stratigraphic correlations of Georgia Geological Survey (GGS) wells 876, 1198, 724, 719, and 1197 in the Southeast (1971), Brown and others (1979), and Gohn and others (1980). Wb, Woodbinian; Wash., Washitan; F-burg., Fredericksburgian; or pre-zone V flora identified by R. A. Christopher (USGS). Depth scale is relative to sea level; stratigraphic boundaries are given 


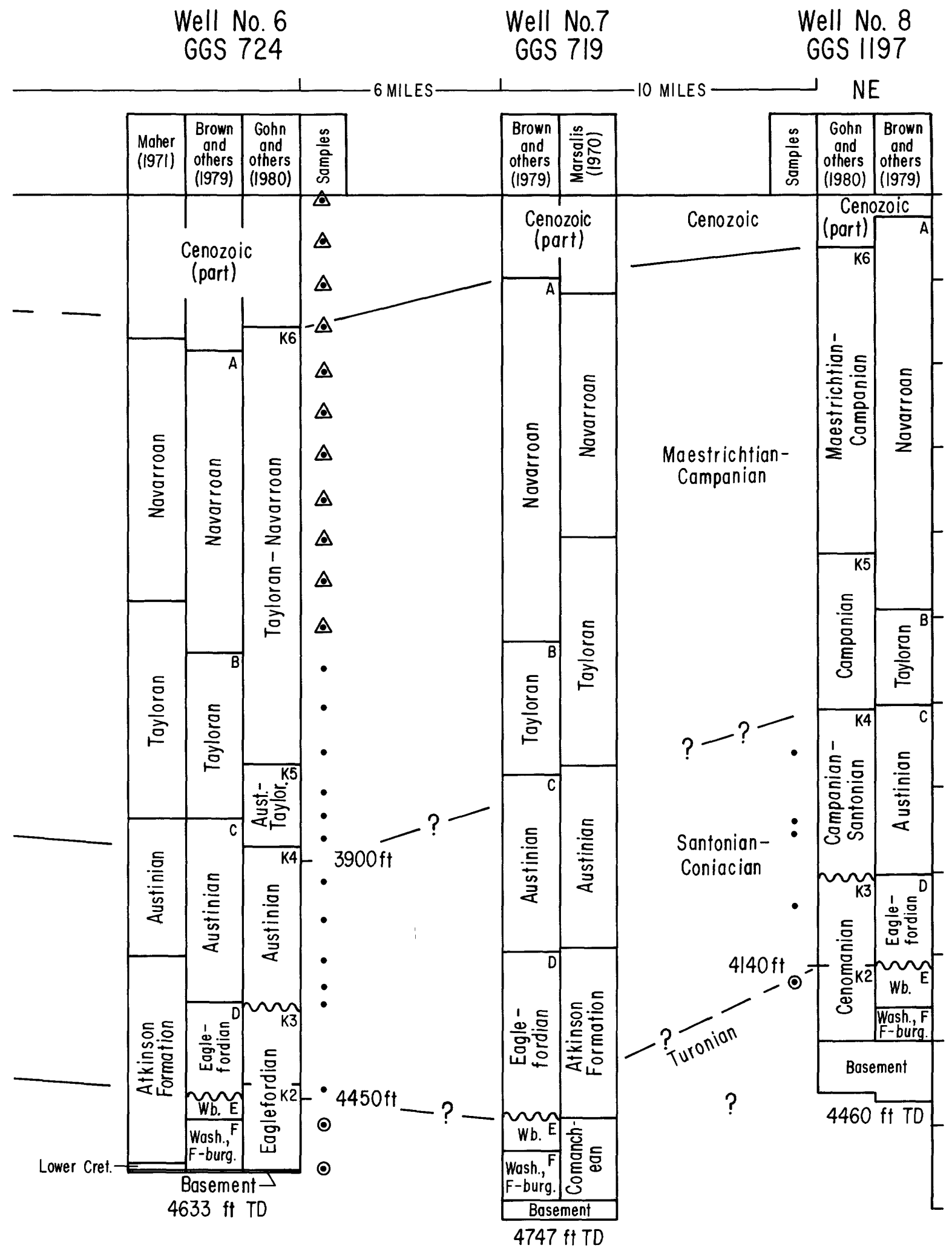

Georgia Embayment, based on the results of this study and showing stratigraphic interpretations of Marsalis (1970), Maher Cret., Cretaceous; Aust., Austinian. Samples shown were originaily part of the study by Gohn and others (1980). Pollen zone IV in original depths (for depth below sea level, subtract $28 \mathrm{ft}$ for GGS 1198, $29 \mathrm{ft}$ for GGS 724, and $24 \mathrm{ft}$ for GGS 1197). 
$\infty$

क :

㟢虫

产
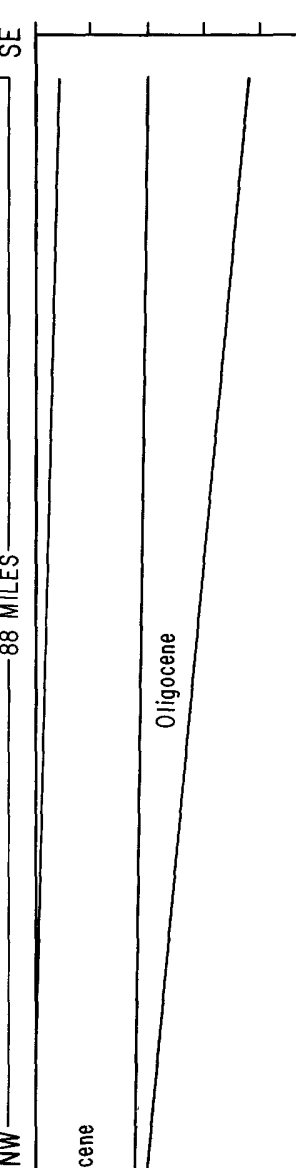

岌

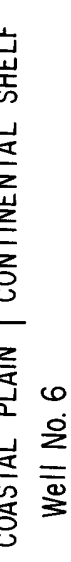

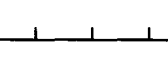

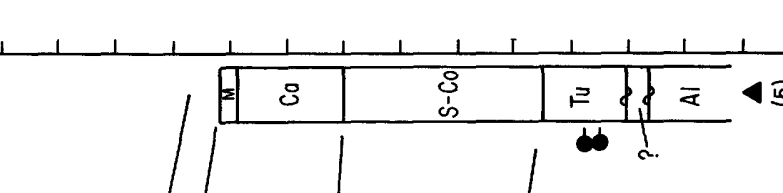


seaward, becoming even thicker $(\sim 30,000 \mathrm{ft})$ beneath the Blake Plateau (Dillon and others, 1979).

Tertiary strata about $2,600 \mathrm{ft}$ thick, principally Eocene limestone, overlie the Upper Cretaceous within the embayment. The Tertiary sedimentary wedge thickens toward the outer shelf, but it thins at the shelf edge and beneath the Florida-Hatteras Slope (not shown in fig. 9) and is only several hundred feet thick beneath the Blake Plateau.

\section{AGES OF SUBSURFACE STRATIGRAPHIC UNITS}

The foregoing analysis is the basis for my reinterpretation of the ages of stratigraphic units that have been delineated in the subsurface of coastal South Carolina and Georgia by previous authors. In figure 10, I show the stratigraphic units of Gohn and others (1978a, 1980 ) and Brown and others (1979) and their relation to the Gulf Coast and European Upper Cretaceous stages as indicated by those authors; I have added my interpretation of the relation of those authors' stratigraphic units to the Upper Cretaceous stages. My stratigraphic interpretations rely on the biostratigraphy of selected wells in coastal South Carolina and Georgia, and the application of my conclusions to adjacent areas depends, in part, on the internal consistency of the stratigraphic framework erected by previous authors; the units identified by Brown and others (1972, 1979), Gohn and others $(1978 \mathrm{a}, 1980)$ may vary somewbat over a large region.

My interpretation of the ages of units A (Navarroan) and B (Tayloran) is essentially the same as that of Brown and others (1979), except that I observe some overlap of the two units at the Navarroan-Tayloran (Maestrichtian-Campanian) boundary. However, I restrict Brown and others' unit C (Austinian) to the upper Austinian (Campanian-Santonian), and I now assign their unit D (Eaglefordian) to the middle and lower Austinian (Santonian-Coniacian). Brown and others (1979) assigned unit $\mathrm{E}$ to the Woodbinian (Cenomanian) Stage and indicated that the unit is absent in the subsurface from the Cape Fear Arch southward to the Parris Island well but that it is consistently present from there into the Southeast Georgia Embayment. My biostratigraphic study of the Fripp Island well and correlation with the nearby Parris Island well shows that unit $\mathrm{E}$ is actually Turonian (middle to late Eaglefordian) in age. In the deep part of the Southeast Georgia Embayment at GGS 724 and GGS 1198, paleontological studies by C. C. Smith and R. A. Christopher (unpub. data, 1978, 1979), as interpreted in the present study, show that unit $\mathrm{E}$ and unit $\mathrm{F}$ (Washitan-Fredericksburgian, lower Cenomanian-Albian) of Brown and others (1979) are Turonian and possibly, in part, late Cenomanian in age. At GGS 144, in the western part of the basin, beds of proven late Cenomanian (Eaglefordian) Age (Hazel, 1969) that are present in the lower member of the Atkinson Formation have been equated with the lower part of unit $\mathrm{E}$ (Woodbinian) by Brown and others (1979). These upper Cenomanian beds contain the "Barlow fauna" and have been found only west and south of the Southeast Georgia Embayment; therefore, I restrict unit E of Brown and others (1979) to the Turonian, as this unit is delineated in the other wells treated in the present study. North of Parris Island and Fripp Island, at the Clubhouse Crossroads core where Brown and others (1979) show unit E to be missing, the newly recognized Turonian interval is equivalent to part of their unit F. I question whether unit $\mathrm{F}$ has been properly delineated or dated within the Southeast Georgia Embayment, especially over the Cape Fear Arch. Figure 10 illustrates the doubtful placement of this unit.

The ages of the stratigraphic units of Gohn and others (1978a, 1980) that represent Maestrichtian, Campanian, and Santonian strata (units $\mathrm{K} 6, \mathrm{~K} 5$, and $\mathrm{K} 4$ ) remain unchanged for the most part in my interpretation (fig. 10). However, those authors recognized a hiatus in the section that represents Coniacian and Turonian time, and they placed units $\mathrm{K} 2$ and $\mathrm{K} 3$ in the upper Cenomanian (middle Eaglefordian) and unit $\mathrm{K} 1$ in the Upper(?) Cretaceous. My recent study of the Fripp Island and Clubhouse Crossroads wells and evaluation of the other well sections discussed above suggests that SantonianConiacian and Turonian strata are present beneath the South Carolina and Georgia coasts. I interpret unit K3 to represent the Coniacian and possibly part of the Santonian (lower Austinian), whereas unit $\mathrm{K} 2$ is Turonian (middle to upper Eaglefordian). Unit K1 is present only in the lowermost part of the sedimentary section in several wells (Clubhouse Crossroads, Parris Island, GGS 363) and may be unfossiliferous. Gohn and others (1978a, 1980), in contrast to Brown and others (1979), did not recognize the presence of any stratigraphic units of early Cenomanian or Albian Age.

\section{GEOLOGIC SECTION OF NORTHERN FLORIDA AND COASTAL GEORGIA AND SOUTH GAROLINA}

The geologic section in figure 11 is based, for the most part, on the biostratigraphy of selected wells in South Carolina and Georgia and the consequent reinterpretation of the ages of stratigraphic units established by Gohn and others (1978a, 1980) and Brown and others (1979). The stratigraphy of the two wells in northern Florida is from Applin and Applin (1967). Figure 11 is broadly similar to a section illustrated in a previous study (Valentine, 1979b, fig. 5), but the Upper Cretaceous stratigraphy is shown in more detail here. A 


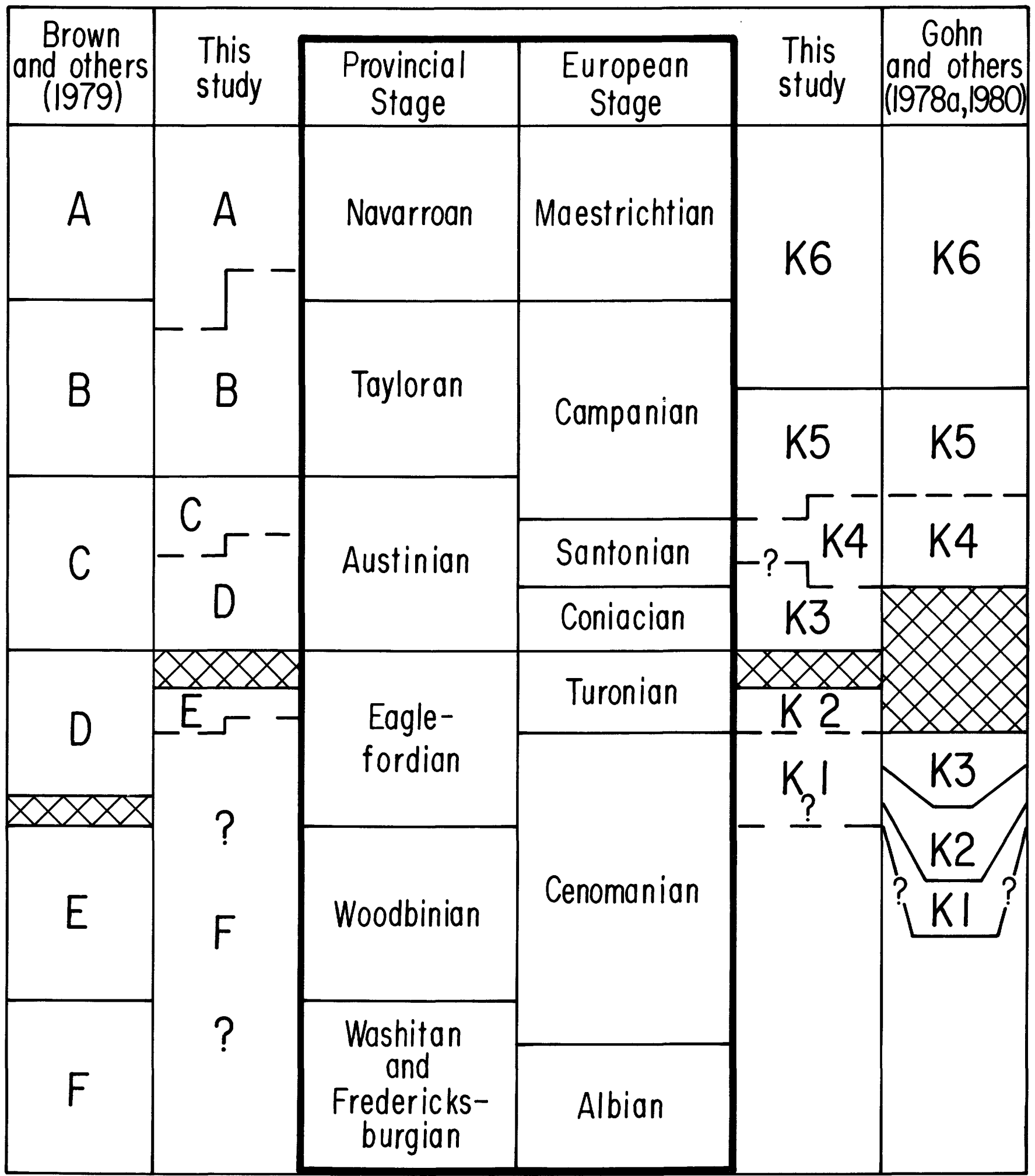

FIGURE 10.- Reinterpretation of the Cretaceous stratigraphic units of coastal Georgia and South Carolina recognized by Gohn and others (1978a, 1980) and Brown and others (1979). Those authors' correlations of their units with Gulf Coast (Provincial) and European stages are shown (as in fig. 2) compared with the new interpretation that has resulted from this study. Cross-hatched zones represent hiatuses. 
comparison of the onshore stratigraphy with the offshore section at COST GE-1 (Valentine, 1979b; Poag and Hall, 1979) is useful in determining the geologic development of the Upper Cretaceous in this region.

The oldest sedimentary rocks in this region are clastic red beds encountered in the subsurface near the Clubhouse Crossroads well that are interlayered with basalt flows of Late Triassic to Early Jurassic age (Gohn and others, 1978b). The lowermost sedimentary unit that is laterally persistent in the Southeast Georgia Embayment basin onshore is a few tens of feet thick and is composed of marginal marine and possibly nonmarine clastic strata that extend northeastward at least as far as the Clubhouse Crossroads core. These beds are poorly fossiliferous, and I infer their age to be Turonian or late Cenomanian, although it is conceivable that they may, in part, represent a remnant of Lower Cretaceous deposits. Herrick and Vorhis (1963) assigned them to the Lower(?) Cretaceous as a result of correlations with dated rocks in northern Florida. This relatively thin unit is confined chiefly to the deep part of the basin; it is bounded below by crystalline and metamorphic basement rocks and above by Turonian marine clastic beds. It appears to represent the late stages of a widespread erosional episode, possibly in Cenomanian time, that resulted in the removal of Lower Cretaceous and perhaps older rocks that were once present beneath the Coastal Plain and are now found only offshore beneath the Continental Shelf. At COST GE-1, on the modern Outer Continental Shelf, a thin sequence (150 ft) of undated shallow marine calcareous sandstone lies between Turonian and Albian strata and may be the erosional or depositional remnant of a Cenomanian regression.

Overlying the oldest sedimentary unit onshore are transgressive lower Turonian marine shale and calcareous sandstone as much as $175 \mathrm{ft}$ thick that extend throughout the Southeast Georgia Embayment beneath the South Carolina and Georgia coasts. Offshore, the Turonian is represented by an argillaceous limestone approximately $400 \mathrm{ft}$ thick at COST GE-1. Turonian beds are inferred to exist northeast of the Clubhouse Crossroads core to at least the Esterville Plantation well (fig. 1) on the basis of the presence of unit K2 of Gohn and others (1978a) and unit $F$ of Brown and others (1979), which I consider to be part Turonian in this region. There is no definitive fossil evidence to determine the age of unit $\mathbf{F}$ in the subsurface farther north.

The stratigraphic interpretation of the lower part of the Cape Fear Arch section in the Myrtle Beach and Calabash wells (fig. 7) by Brown and others (1979) is quite different from that by Gohn and others (1978a). Brown and others (1979) placed the lowermost beds in unit F (Washitan and Fredericksburgian; Cenomanian and Albian) and indicated that they are overlain uncon- formably by beds of unit D (Eaglefordian; Turonian and upper Cenomanian). The same beds were placed by Gohn and others (1978a) in unit K3 (middle Eaglefordian; upper Cenomanian), and they did not recognize an unconformity within the unit. I interpret these strata to be at least partly Santonian-Coniacian in age (fig. 7). Moreover, Christopher and others (1979) have reported that the Cape Fear Formation, near its type locality on the Cape Fear Arch in south-central North Carolina, contains a pollen zone $\mathrm{V}$ flora, now known to range in age from possibly Coniacian to Santonian and early Campanian (R. A. Christopher, oral commun., 1979). The Cape Fear Formation overlies crystalline basement in this region, and Christopher and others (1979) have therefore shown that Cenomanian and Lower Cretaceous rocks are not present on the Cape Fear Arch, at least near the inner edge of the Coastal Plain. At the coast, the Upper Cretaceous section thins somewhat over the Cape Fear Arch (fig. 11), and sedimentary strata of Cenomanian and Albian Age may not be present there either. Rather, Santonian and Coniacian and possibly Turonian rocks overlie preCretaceous crystalline basement, and the Upper Cretaceous-Lower Cretaceous boundary may be offshore beneath the Continental Shelf.

Santonian-Coniacian strata constitute a marine clastic interval about $650 \mathrm{ft}$ thick that extends from the Cape Fear Arch southwestward along the coast into the basin, where in southeastern Georgia and northeastern Florida the uppermost beds are marine carbonates. The Santonian-Coniacian rocks are somewhat coarser than the underlying Turonian beds, and the Coniacian part of the sequence may represent a regressive shallowing succeeded by further transgression during the Santonian, although a hiatus within these strata has not been documented yet. At COST GE-1, marine carbonate shelf conditions prevailed during the Santonian and Coniacian.

The combined Maestrichtian and Campanian stages range in thickness from $650 \mathrm{ft}$ at the Cape Fear Arch to $1,225 \mathrm{ft}$ in southeast Georgia and are part of an extensive transgressive sequence in this region. The Maestrichtian-Campanian boundary cannot be distinguished paleontologically in the center of the Southeast Georgia Embayment. Marine clastic beds were deposited on the southern flank of the present Cape Fear Arch throughout Maestrichtian-Campanian time, but the center of the embayment onshore became a marine carbonate province that formed northeastward, transgressing the Cape Fear Arch in the Eocene. The Upper Cretaceous and Tertiary marine carbonates constitute a thick sequence that was deposited in the center of the embayment until post-Oligocene time; the coeval Tertiary section in the Cape Fear Arch region is much 
PENINSULAR ARCH

A SW Fla.IGa.
SOUTHEAST GEORGIA EMBAYMENT

Ga.I S.C.

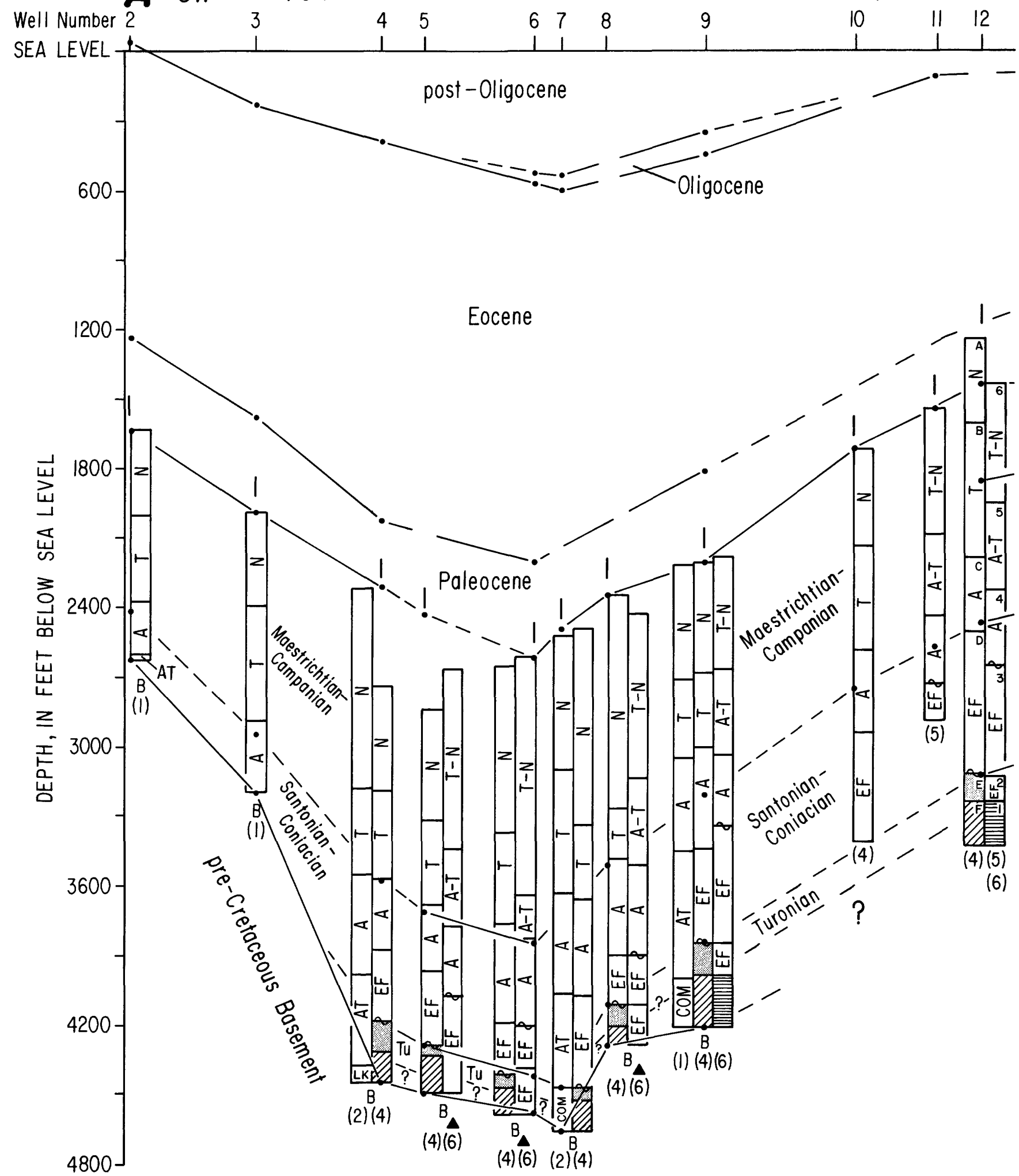

FIGURE 11. - Stratigraphic correlation along section $\boldsymbol{A}-\boldsymbol{A}^{\prime}$ through the Southeast Georgia Embayment and the Cape Fear Arch, northern Florida and Applin (1967); (2) Marsalis (1970); (3) Brown and others (1972); (4) Brown and others (1979); (5) Gohn and others (1978a); (6) Gohn and European-stage terminology; the Parris Island (12) and Fripp Island (13) sections include the letters and numbers used by Gohn and others 


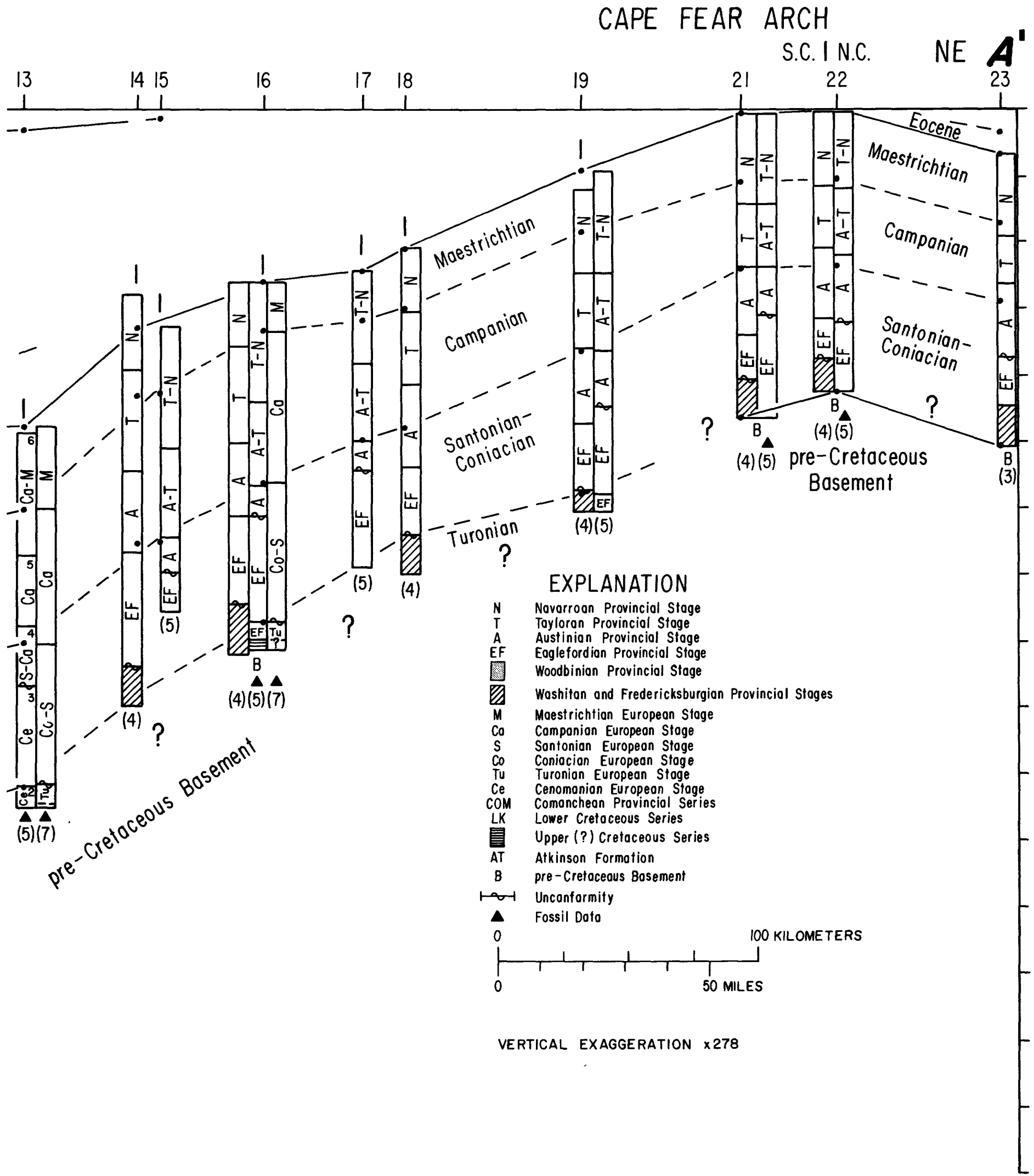

and coastal Georgia and South Carolina, showing stratigraphic interpretation of this study and interpretations of individual wells by: (1) Applin others (1980); and (7) Valentine (this study). The stratigraphy of the Fripp Island well (13) and the Clubhouse Crossroads corehole 1 (16) includes (1978a, 1980) and by Brown and others (1979) to designate their stratigraphic units. 
thinner and is characterized by disconformities. At COST GE-1, Maestrichtian and Campanian limestones were deposited at depths that today are equated with marine shelf and upper slope conditions; they, in turn, are overlain by Paleogene shelf carbonate rocks.

The distribution, thickness, and configuration of the Upper Cretaceous Series and Tertiary System throughout the Southeast Georgia Embayment show that a marked change took place in the formational style of the continental margin from Late Cretaceous to early Tertiary time (Valentine, 1979b). In coastal South Carolina and Georgia, as well as offshore, the thickness of the Upper Cretaceous Series is more uniform than that of the Cenozoic strata. The Eocene, in particular, is very thick at the center of the basin and all but absent on the Cape Fear Arch. In Late Cretaceous and Paleocene time, deposition took place on a gently dipping continental margin that subsided regionally. In contrast, during the Eocene, the present Continental Shelf formed by progradation (Schlee, 1977; Paull and Dillon, 1980) in response to both the rapid accumulation of a large volume of carbonate sediments and more localized subsidence of the margin. Eocene deposits became very thick to form the present Southeast Georgia Embayment, but they remained thin over the relatively stable Cape Fear Arch and have been eroded during subsequent regressions during the Tertiary and Quaternary. The margin has continued to form in this manner throughout post-Eocene time.

\section{SUMMARY}

The Upper Cretaceous stratigraphy of coastal Georgia and South Carolina has been reevaluated through new biostratigraphic analyses in conjunction with a comparative study of recent stratigraphic interpretations of the region by other workers, interpretations that were in large part based on the same well sections. I am in agreement with the age assignments of the younger Upper Cretaceous stratigraphic units of Brown and others (1979) and Gohn and others (1978a, 1980), but I consider the older units to be significantly younger than those authors indicated.

There are no accepted type sections for the Cenomanian and Turonian stages in Europe, and, as a result, the placement of the boundary is in dispute. The Cenomanian-Turonian boundary apparently is within the Sciponoceras gracile ammonite zone, which forms a boundary interval between the upper Cenomanian Calycoceras naviculare zone and the lower Turonian Mammites nodosoides/Inoceramus labiatus zone. The foraminifer genus Rotalipora becomes extinct in the Sciponoceras gracile zone in both Europe and the United States Western Interior; this datum is a practical basis for recognizing the Cenomanian-Turonian boundary.
On the Atlantic margin, calcareous nannofossils of chiefly early Turonian age are found with spores and pollen characteristic of pollen zone IV (ComplexiopollisAtlantopollis assemblage zone). These assemblages also occur together in the Gulf Coastal Plain. In a cored section at Dallas, Tex., Turonian nannofossils are found in pollen zone IV, as delineated by Christopher (in press) in the middle and upper part of the Britton Formation and the lower part of the Arcadia Park Formation; this interval encompasses the Sciponoceras gracile ammonite zone and the lower part of the Mytiloides labiatus mollusk zone identified in equivalent sections exposed near the corehole (J. D. Powell, oral and written commun., 1980).

Gohn and others $(1978 \mathrm{a}, 1980)$ postulated a major hiatus encompassing Coniacian and Turonian time and identified several units of Cenomanian Age in the Southeast Georgia Embayment and on the Cape Fear Arch. In contrast, I believe that Coniacian and Turonian strata exist in this region and that Cenomanian beds, if present, are poorly represented in the interval just above pre-Cretaceous basement rocks.

I interpret the ages of the stratigraphic units established by Brown and others (1979) as follows: unit A (Navarroan) and unit B (Tayloran), both unchanged; unit C (Austinian), now restricted to a late Austinian (early Campanian and Santonian) Age; unit D (Eaglefordian), now assigned a middle and early Austinian (Santonian and Coniacian) Age; unit E (Woodbinian), now assigned a late and middle Eaglefordian (Turonian) Age; and unit F (Washitan and Fredericksburgian), now assigned an Eaglefordian and questionable Woodbinian or older Age.

The ages of the stratigraphic units of Gohn and others (1978a, 1980) are interpreted as follows: unit K6 (Maestrichtian-Campanian; Navarroan-Tayloran), unit K5 (Campanian; Tayloran-Austinian), and unit K4 (Campanian-Santonian; Austinian), all unchanged; unit K3 (late Cenomanian; middle Eaglefordian), now assigned a Santonian(?)-Coniacian (Austinian) Age; unit K2 (late Cenomanian; middle Eaglefordian), now assigned a Turonian (late and middle Eaglefordian) Age; and unit K1 (Late(?) Cretaceous), now questionably assigned a Turonian and Cenomanian Age.

These conclusions are fundamental to a reconstruction of the geologic history of the region. Lower Cretaceous rocks were removed from the present coastal region of South Carolina and Georgia during a widespread erosional episode in Cenomanian time, leaving a thin unit of unfossiliferous beds of probably nonmarine origin overlying pre-Cretaceous basement. Offshore, Albian and Turonian strata are separated by a thin sequence of undated shallow marine beds of possible Cenomanian Age. Lower Turonian marine shale onshore is probably 
separated by a hiatus from Coniacian through Maestrichtian marine clastic strata. The upper Turonian hiatus and the coarser Coniacian beds may mark a period of regressive shallowing, and the Santonian, Campanian, and Maestrichtian strata are part of a transgressive sequence that in southeastern Georgia became a carbonate province in Campanian and Maestrichtian time. Turonian through Maestrichtian marine limestone is present offshore beneath the Outer Continental Shelf.

On a regional scale, Upper Cretaceous sediments were deposited on a broadly subsiding continental margin that included the present Georgia and South Carolina Coastal Plain, the Continental Shelf, and the Blake Plateau. During the Tertiary, however, a large volume of chiefly carbonate sediment was deposited in a subsiding region focused on the Southeast Georgia Embayment. Upper Cretaceous and basement rocks were warped downward south of the relatively stable Cape Fear Arch region, as a progradational Continental Shelf formed on the western margin of the continually subsiding and sediment-starved Blake Plateau.

\section{REFERENCES CITED}

Amato, R. V., and Bebout, J. W., 1978, Geological and operational summary, COST GE-1 well, Southeast Georgia Embayment area, South Atlantic OCS: U.S. Geological Survey Open-File Report 78-668, $122 \mathrm{p}$.

Applin, E. R., 1955, A biofacies of Woodbine age in the southeastern Gulf Coast region: U.S. Geological Survey Professional Paper 264-I, p. 187-197.

Applin, P. L., and Applin, E. R., 1965, The Comanche Series and associated rocks in the subsurface in central and south Florida: U.S. Geological Survey Professional Paper 447, 84 p.

1967, The Gulf Series in the subsurface in northern Florida and southern Georgia: U.S. Geological Survey Professional Paper 524-G, 35 p.

Ascoli, P., 1976, Foraminiferal and ostracod biostratigraphy of the Mesozoic-Cenozoic, Scotian Shelf, Atlantic Canada: Maritime Sediments Special Publication 1, pt. B, p. 653-771.

Barrier, J., 1980, A revision of the stratigraphic distribution of some Cretaceous coccoliths in Texas: Journal of Paleontology, v. 54, no. 2, p. 289-308.

Basse, E. de Menorval, 1959, Le domaine d'influence boréale, in Congrès des Sociétés Savantes de Paris et des Départements, Dijon, 1959, Section des Sciences, Sous-section de Géologie, Comptes Rendus, Colloque sur le Crétacé Supérieur Français: Paris, Gauthier-Villars, p. 799-814.

Brown, C. W., and Pierce, R. L., 1962, Palynologic correlations in Cretaceous Eagle Ford Group, northeast Texas: American Association of Petroleum Geologists Bulletin, v. 46, no. 12, p. 2133-2147.

Brown, P. M., Brown, D. L., Reid, M. S., and Lloyd, O. B., 1979, Evaluation of the geologic and hydrologic factors related to the waste-storage potential of Mesozoic aquifers in the southern part of the Atlantic Coastal Plain, South Carolina and Georgia: U.S. Geological Survey Professional Paper 1088, 37 p.
Brown, P. M., Miller, J. A., and Swain, F. M., 1972, Structural and stratigraphic framework, and spatial distribution of permeability of the Atlantic Coastal Plain, North Carolina to New York: U.S. Geological Survey Professional Paper 796, 79 p.

Bukry, David, 1969, Upper Cretaceous coccoliths from Texas and Europe: Kansas University Paleontological Contributions [51], Protista 2, 79 p.

Christopher, R. A., 1977, Selected normapolles pollen genera and the age of the Raritan and Magothy Formations (Upper Cretaceous) of northern New Jersey, in Owens, J. P., Sohl, N. F., and Minard, J. P., eds., A field guide to Cretaceous and lower Tertiary beds of the Raritan and Salisbury Embayments, New Jersey, Delaware, and Maryland: American Association of Petroleum Geologists - Society of Economic Paleontologists and Mineralogists, Guidebook for Annual Convention, Washington, D.C., June 12-16, 1977, p. 58-69. 1979, Normapolles and triporate pollen assemblages from the Raritan and Magothy Formations (Upper Cretaceous) of New Jersey: Palynology, v. 3, p. 73-121.

in press, The occurrence of the Complexiopollis-Atlantopollis zone (palynomorphs) in the Eagle Ford Group (Upper Cretaceous) of Texas: Journal of Paleontology.

Christopher, R. A., Owens, J. P., and Sohl, N. F., 1979, Late Cretaceous palynomorphs from the Cape Fear Formation of North Carolina: Southeastern Geology, v. 20, no. 3, p. 145-159.

Cobban, W. A., and Reeside, J. B., Jr., 1952, Correlation of the Cretaceous formations of the Western Interior of the United States: Geological Society of America Bulletin, v. 63, no. 10, p. 1011-1043.

Cobban, W. A., and Scott, G. R., 1972, Stratigraphy and ammonite fauna of the Graneros Shale and Greenhorn Limestone near Pueblo, Colorado: U.S. Geological Survey Professional Paper 645, $108 \mathrm{p}$.

Cramer, H. R., 1974, Isopach and lithofacies analyses of the Cretaceous and Cenozoic rocks of the Coastal Plain of Georgia: Georgia Geological Survey Bulletin 87, p. 21-44.

Dillon, W. P., Paull, C. K., Dahl, A. G., and Patterson, W. C., 1979, Structure of the continental margin near the COST No. GE-1 drill site from a common depth-point seismic-reflection profile, in Scholle, P. A., ed., Geological studies of the COST GE-1 well, United States South Atlantic Outer Continental Shelf area: U.S. Geological Survey Circular 800, p. 97-107.

Doyle, J. A., 1969a, Angiosperm pollen evolution and biostratigraphy of the basal Cretaceous formations of Maryland, Delaware, and New Jersey [abs.]: Geological Society of America Abstracts with Programs, [v. 1] pt. 7, p. 51.

$-1969 \mathrm{~b}$, Cretaceous angiosperm pollen of the Atlantic Coastal Plain and its evolutionary significance: Harvard University, Arnold Arboretum Journal, v. 50, p. 1-35.

1977, Spores and pollen; the Potomac Group (Cretaceous) angiosperm sequence, in Kauffman, E. G., and Hazel, J. E., eds., Concepts and methods of biostratigraphy: Stroudsburg, Pa., Dowden, Hutchinson and Ross, p. 339-363.

Doyle, J. A., and Robbins, E. I., 1977, Angiosperm pollen zonation of the continental Cretaceous of the Atlantic Coastal Plain and its application to deep wells in the Salisbury Embayment: Palynology, v. 1, p. 43-78.

Eicher, D. L., and Worstell, Paula, 1970, Cenomanian and Turonian Foraminifera from the Great Plains, United States: Micropaleontology, v. 16, no. 3, p. 269-324.

Gartner, Stefan, Jr., 1968, Coccoliths and related calcareous nannofossils from Upper Cretaceous deposits of Texas and Arkansas: Kansas University Paleontological Contributions [48], Protista 1, $56 \mathrm{p}$. 
Gohn, G. S., Bybell, L. M., Christopher, R. A., Owens, J. P., and Smith, C. C., in press, A stratigraphic framework for Cretaceous and Paleogene sediments along the South Carolina and Georgia coastal margins, in Arden, D. D., and Beck, B. F., eds., Southeastern Coastal Plain Geology, Symposium: Georgia Geological Survey Bulletin.

Gohn, G. S., Christopher, R. A., Smith, C. C., and Owens, J. P., 1978a, Preliminary stratigraphic cross sections of Atlantic Coastal Plain sediments of the Southeastern United States-Cretaceous sediments along the South Carolina coastal margin: U.S. Geological Survey Miscellaneous Field Studies Map MF-1015-A.

Gohn, G. S., Gottfried, D., Lanphere, M. A., and Higgins, B. B., 1978b, Regional implications of Triassic or Jurassic age for basalt and sedimentary red beds in the South Carolina Coastal Plain: Science, v. 202 , no. 4370 , p. $887-889$.

Gohn, G. S., Higgins, B. B., Smith, C. C., and Owens, J. P., 1977, Lithostratigraphy of the deep corehole (Clubhouse Crossroads Corehole 1) near Charleston, South Carolina: U.S. Geological Survey Professional Paper 1028-E, p. 59-70.

Gohn, G. S., Smith, C. C., Christopher, R. A., and Owens, J. P., 1980, Preliminary stratigraphic cross sections of Atlantic Coastal Plain sediments of the Southeastern United States-Cretaceous sediments along the Georgia coastal margin: U.S. Geological Survey Miscellaneous Field Studies Map MF-1015-C.

Hancock, J. M., 1959, Les ammonites du Cénomanien de la Sarthe, in Congrès des Sociétés Savantes de Paris et des Départements, Dijon, 1959, Section des Sciences, Sous-Section de Géologie, Comptes Rendus, Colloque sur le Crétacé Supérieur Français: Paris, Gauthier-Villars, p. 249-252.

Hathaway, J. C., Poag, C. W., Valentine, P. C., Miller, R. E., Schultz, D. M., Manheim, F. T., Kohout, F. A., Bothner, M. H., and Sangrey, D. A., 1979, U.S. Geological Survey core drilling on the Atlantic Shelf: Science, v. 206, no. 4418, p. 515-527.

Hattin, D. E., 1965, Stratigraphy of the Graneros Shale (Upper Cretaceous) in central Kansas: Kansas Geological Survey Bulletin $178,83 \mathrm{p}$.

1975, Stratigraphy and depositional environment of Greenhorn Limestone (Upper Cretaceous) of Kansas: Kansas Geological Survey Bulletin 209, $128 \mathrm{p}$.

Hattner, J. G., and Wise, S. W., Jr., 1979, Calcareous nannofossils from the type section of the Peedee Formation (Cretaceous) and neighboring localities in South Carolina: Geological Society of America Abstracts with Programs, v. 11, no. 4, p. 182.

1980, Upper Cretaceous calcareous nannofossil biostratigraphy of South Carolina: South Carolina Geology, v. 24, no. 2, p. 41-117.

Hazel, J. E., 1969, Cythereis eaglefordensis Alexander, 1929-A guide fossil for deposits of latest Cenomanian age in the western interior and Gulf Coast regions of the United States: U.S. Geological Survey Professional Paper 650-D, p. D155-D158.

Hazel, J. E., Bybell, L. M., Christopher, R. A., Fredericksen, N. O., May, F. E., McLean, D. M., Poore, R. Z., Smith, C. C., Sohl, N. F., Valentine, P. C., and Witmer, R. J., 1977, Biostratigraphy of the deep corehole (Clubhouse Crossroads Corehole 1) near Charleston, South Carolina: U.S. Geological Survey Professional Paper 1028-F, p. 71-89.

Herrick, S. M., 1961, Well logs of the Coastal Plain of Georgia: Georgia Geological Survey Bulletin 70, $461 \mathrm{p}$.

Herrick, S. M., and Vorhis, R. C., 1963, Subsurface geology of the Georgia Coastal Plain: Georgia Geological Survey Information Circular 25, $78 \mathrm{p}$.

International Biostratigraphers, Inc., 1977, Biostratigraphy of the COST No. GE-1 well Georgia Embayment test: Houston, Texas, 16 p. (Available for public inspection at the U.S. Geological Survey, 1725 K Street, N.W., Washington, D.C.)
Jefferies, R. P. S., 1962, The paleoecology of the Actinocamax plenus subzone (lowest Turonian) in the Anglo-Paris basin: Palaeontology, v. 4, p. 609-647.

Juignet, P., 1976, Présentation du Crétacé moyen dans l'ouest de la France: remarques sur les stratotypes du Cénomanien et du Turonien, in Reyment, R. A., and Thomel, G., eds., Événements de la partie moyenne du Crétacé ${ }^{* * *}$ : Muséum d'Histoire Naturelle Nice Annales, v. 4, p. 2.1-2.12 [1979].

Juignet, P., Kennedy, W. J., and Lebert, A., 1978, Le Cénomanien du Maine; formations sédimentaires et faunes d'ammonites du stratotype: Provence Université, Annales, Géologie Méditerranéene, v. 5, no. 1, p. 87-99.

Kauffman, E. G., Cobban, W. A., and Eicher, D. L., 1976, Albian through lower Coniacian strata, biostratigraphy and principal events, western interior United States, in Reyment, R. A., and Thomel, Gérard, eds., Événements de la partie moyenne du

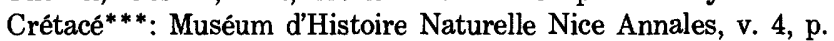
23.1-23.52 [1979].

Kauffman, E. G., Hattin, D. E., and Powell, J. D., 1977, Stratigraphic, paleontologic, and paleoenvironmental analysis of the Upper Cretaceous rocks of Cimarron County, northwestern Oklahoma: Geological Society of America Memoir 149, $150 \mathrm{p}$.

Kennedy, W. J., 1969, The correlation of the Lower Chalk of southeast England: Geologists Association Proceedings, v. 80, pt. 4, p. 459-551.

Kennedy, W. J., and Hancock, J. M., 1976, The mid-Cretaceous of the United Kingdom, in Reyment, R. A., and Thomel, Gérard, eds., Événements de la partie moyenne du Crétacé***: Muséum d'Histoire Naturelle Nice Annales, v. 4, p. 5.1-5.72 [1979].

Kennedy, W. J., and Juignet, P., 1973, Observations on the lithostratigraphy and ammonite succession across the Cenomanian-Turonian boundary in the environs of LeMans (Sarthe, N.W. France): Newsletters on Stratigraphy, v. 2, no. 4, p. 189-202.

Lecointre, Georges, 1959, Le Turonian dans sa région type, la Touraine, in Congrès des Sociétés Savantes de Paris et des Départements, Dijon, 1959, Section des Sciences, Sous-Section de Géologie, Comptes Rendus, Colloque sur le Crétacé Supérieur Français: Paris, Gauthier-Villars, p. 415-423.

Magné, Jean, and Polvêche, J., 1961, Sur le niveau à Actinocamax plenus (Blainville) du Boulonnais: Société Géologique du Nord Annales, v. 81 , pt. 1 , p. $47-62$.

Maher, J. C., 1971, Geologic framework and petroleum potential of the Atlantic Coastal Plain and Continental Shelf: U.S. Geological Survey Professional Paper 659, $98 \mathrm{p}$.

Manivit, H., Bick, A., and others, 1979, Calcareous nannofossil events in the Lower and Middle Cretaceous: INA Newsletter (International Nannoplankton Association Proceedings) v. 1., no. 1, p. N7.

Manivit, H., Perch-Nielsen, K., Prins, B., and Verbeek, J. W., 1977, Mid-Cretaceous calcareous nannofossil biostratigraphy: Nederlandse Akademie van Wetenschappen Proceedings, Series B, v. 80 , p. $169-181$.

Marks, P., 1977, Micropaleontology and the Cenomanian-Turonian boundary problem: Nederlandse Akademie van Wetenschappen Proceedings, Ser. B, v. 80, p. 1-6.

Marsalis, W. E., 1970, Petroleum exploration in Georgia: Georgia Geological Survey Information Circular 38, $52 \mathrm{p}$.

Orbigny, A. d', 1840-1842, Céphalopodes, v. 1 of Terrains Crétacés: Paris, V. Masson, $662 \mathrm{p}$.

1847, Brachiopodes, v. 4 of Terrains Crétacés: Paris, V. Masson, $390 \mathrm{p}$.

Paull, C. K., and Dillon, W. P., 1980, Structure, stratigraphy and geologic history of Florida-Hatteras Shelf and inner Blake Plateau: American Association of Petroleum Geologists Bulletin, no. 3, v. 63, p. 339-358. 
Perry, W. J., Minard, J. P., Weed, E. G. A., Robbins, E. I., and Rhodehamel, E. C., 1975, Stratigraphy of Atlantic coastal margin of United States north of Cape Hatteras; brief survey: American Association of Petroleum Geologists Bulletin, v. 59, no. 9, p. 1529-1548.

Pessagno, E. A., Jr., 1969, Upper Cretaceous stratigraphy of the western Gulf Coast area of Mexico, Texas, and Arkansas: Geological Society of America Memoir 111, 139 p.

Petters, S. W., 1976, Upper Cretaceous subsurface stratigraphy of Atlantic Coastal Plain of New Jersey: American Association of Petroleum Geologists Bulletin, v. 60, no. 1, p. 87-107.

Poag, C. W., and Hall, R. E., 1979, Foraminiferal biostratigraphy, paleoecology, and sediment accumulation rates, in Scholle, P. A., ed., Geological studies of the COST GE-1 well, United States South Atlantic Outer Continental Shelf area: U.S. Geological Survey Circular 800, p. 49-63.

Porthault, Bernard, Thomel, Gérard, and Villoutreys, O. de, 1967, Étude biostratigraphique du Cénomanien du bassin supérieur de l'Estéron (Alpes-Maritimes); le problème de la limite CénomanienTuronien dans le sud-est de la France: Société Géologique de France Bulletin, Sér. 7, v. 8 (1966), no. 3, p. 423-439.

Rawson, P. F., Curry, D., and others, 1978, A correlation of Cretaceous rocks in the British Isles: Geological Society of London Special Report 9, 70 p.

Robaszynski, Francis, 1971, Les foraminifères pélagiques des "Dièves" crétacées aux abords du golfe de Mons (Belgique): Société Géologique du Nord Annales, v. 91, no. 1, p. 31-38.

1976, Approche biostratigraphique du Cénomano-Turonien dans le Hainaut Franco-Belge et le nord de la France, in Reyment, R. A., and Thomel, Gérard, eds., Evénements de la partie moyenne de Crétacé***: Muséum d'Histoire Naturelle Nice Annales, v. 4, p. 8.1-8.23 [1979].

Robaszynski, Francis, and Caron, Michèle, eds., 1979, Atlas de foraminifères planctoniques du Crétacé moyen (Mer Boréale et Tethys), v. 1: Cahiers du Micropaléontologie, 1979, no. 1, 185 p.

Roth, P. H., and Thierstein, H. R., 1972, Calcareous nannoplankton; Leg 14 of the Deep Sea Drilling Project, in California University, Scripps Institution of Oceanography, La Jolla, Initial reports of the Deep Sea Drilling Project, v. $14^{* * *}$ : Washington, D.C., U.S. National Science Foundation, p. 421-485.

Schlee, John, 1977, Stratigraphy and Tertiary development of the continental margin east of Florida: U.S. Geological Survey Professional Paper 581-F, $25 \mathrm{p}$.

Scholle, P. A., ed., 1979, Geological studies of the COST GE-1 well, United States South Atlantic Outer Continental Shelf area: U.S. Geological Survey Circular 800, $114 \mathrm{p}$.

Sirkin, L. A., 1974, Palynology and stratigraphy of Cretaceous strata in Long Island, New York, and Block Island, Rhode Island: U.S. Geological Survey Journal of Research, v. 2, no. 4, p. 431-440.

Smith, C. C., 1975, Upper Cretaceous calcareous nannoplankton zonation and stage boundaries: Gulf Coast Association Geological Societies Transactions, v. 25, p. 263-278.

1981, Calcareous nannoplankton and stratigraphy of late Turonian, Coniacian, and early Santonian Age of the Eagle Ford and Austin Groups of Texas: U.S. Geological Survey Professional Paper 1075, $98 \mathrm{p}$.
Thierstein, H. R., 1973, Lower Cretaceous calcareous nannoplankton biostratigraphy: [Austria] Geologisches Bundesanstalt Abhandlungen, v. 29, $52 \mathrm{p}$.

-1974, Calcareous nannoplankton; Leg 26 of the Deep Sea Drilling Project, in California University, Scripps Institution of Oceanography, La Jolla, Initial reports of the Deep Sea Drilling Project, v. $26 * * *$ : Washington, D.C., U.S. National Science Foundation, p. 619-667.

1976, Mesozoic calcareous nannoplankton biostratigraphy of marine sediments: Marine Micropalaeontology, v. 1, no. 4, p. 325-362.

Toulmin, L. D., 1955, Cenozoic geology of southeastern Alabama, Florida, and Georgia: American Association of Petroleum Geologists Bulletin, v. 39, no. 2, p. 207-235.

Valentine, P. C., 1977, Nannofossil biostratigraphy, in Scholle, P. A. ed., Geological studies on the COST No. B-2 well, U.S. MidAtlantic Outer Continental Shelf area: U.S. Geological Survey Circular 750, p. 37-40.

1979a, Calcareous nannofossil biostratigraphy and paleoenvironmental interpretation, in Scholle, P. A., ed., Geological studies of the COST GE-1 well, United States South Atlantic Outer Continental Shelf area: U.S. Geological Survey Circular 800, p. $64-70$.

1979b, Regional stratigraphy and structure of the Southeast Georgia Embayment, in Scholle, P. A., ed., Geological studies of the COST GE-1 well, United States South Atlantic Outer Continental Shelf area: U.S. Geological Survey Circular 800, p. 7-17.

-1980, Calcareous nannofossil biostratigraphy, paleoenvironments, and post-Jurassic continental margin development, in Scholle, P. A., ed., Geological studies of the COST No. B-3 well, United States Mid-Atlantic Continental Slope area: U.S. Geological Survey Circular 833, p. 67-84.

van Hinte, J. E., 1976, A Cretaceous time scale: American Association of Petroleum Geologists Bulletin, v. 60, no. 4, p. 498-516.

Verbeek, J. W., 1976, Upper Cretaceous calcareous nannoplankton zonation in a composite section near El Kef, Tunisia: Nederlandse Akademie van Wetenschappen Proceedings, Ser. B., v. 79, no. 2, p. 129-148.

1977a, Calcareous nannoplankton biostratigraphy of Middle and Upper Cretaceous deposits in Tunisia, southern Spain, and France: Utrecht Micropaleontological Bulletins, v. 16, $157 \mathrm{p}$.

1977b, Late Cenomanian to early Turonian calcareous nannofossils from a section SE of Javernant (Dept. Aube, France): Nederlandse Akademie van Wetenschappen Proceedings, Ser. B., v. 80 , no. 1 , p. 20-22.

Vries, H. E. de, 1977, Late Cenomanian to early Turonian planktonic Foraminifera from a section SE of Javernant (Dept. Aube, France): Nederlandse Akademie van Wetenschappen Proceedings, Ser. B, v. 80 , no. 1, p. 23-38.

Wonders, A. A. H., and Verbeek, J. W., 1977, Correlation of planktonic foraminiferal and calcareous nannofossil zonations of late Albian, Cenomanian and Turonian: Nederlandse Akademie van Wetenschappen Proceedings, Ser. B, v. 80, no. 1, p. 7-15.

Zupan, A. J., and Abbott, W. H., 1976, Comparative geology of onshore and offshore South Carolina, in Hathaway, J. C., and others, eds., Preliminary summary of the 1976 Atlantic Margin Coring Project of the U.S. Geological Survey: U.S. Geological Survey Open-File Report 76-844, p. 206-214. 